\title{
Discovery of Highly Selective Inhibitors of Calmodulin-Dependent Kinases That Restore Insulin Sensitivity in the Diet-Induced Obesity in Vivo Mouse Model
}

Christophe Fromont, Alessio Atzori, Divneet Kaur, Lubna Hashmi, Graziella Greco, Alejandro Cabanillas, Huy Van Nguyen, D. Heulyn Jones, Miguel Garzón, Ana Varela, Brett Stevenson, Greg P. Iacobini, Marc Lenoir, Sundaresan Rajesh, Clare Box, Jitendra Kumar, Paige Grant, Vera Novitskaya, Juliet Morgan, Fiona J. Sorrell, Clara Redondo, Andreas Kramer, C. John Harris, Brendan Leighton, Steven P. Vickers, Sharon C. Cheetham, Colin Kenyon, Anna M. Grabowska, Michael Overduin, Fedor Berditchevski, Chris J. Weston, Stefan Knapp, Peter M. Fischer, and Sam Butterworth*

Cite This: J. Med. Chem. 2020, 63, 6784-6801

Read Online

ACCESS | Lلll Metrics \& More | 回 Article Recommendations | si Supporting Information

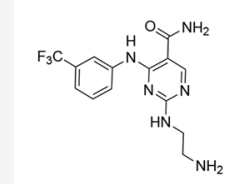

Literature SYK inhibitor

$S Y K I C_{50}=7 \mathrm{nM}$ CaMK1D IC $_{50}=436 \mathrm{nM}$

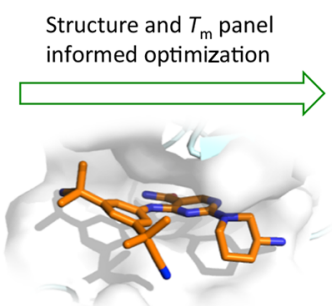

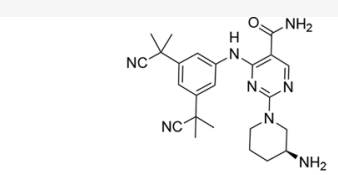

CaMK1 in vivo tool compounds CaMK1D IC $C_{50}=31 \mathrm{nM}$ pCaMK1D cell assay IC $\mathrm{I}_{50}=8 \mathrm{nM}$ >150-fold selective over non-CaMK1 kinases Active in DIO mouse model

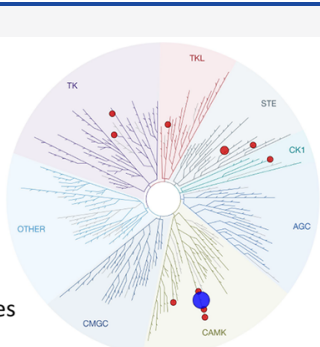

ABSTRACT: Polymorphisms in the region of the calmodulin-dependent kinase isoform D (CaMK1D) gene are associated with increased incidence of diabetes, with the most common polymorphism resulting in increased recognition by transcription factors and increased protein expression. While reducing CaMK1D expression has a potentially beneficial effect on glucose processing in human hepatocytes, there are no known selective inhibitors of CaMK1 kinases that can be used to validate or translate these findings. Here we describe the development of a series of potent, selective, and drug-like CaMK1 inhibitors that are able to provide significant free target cover in mouse models and are therefore useful as in vivo tool compounds. Our results show that a lead compound from this series improves insulin sensitivity and glucose control in the diet-induced obesity mouse model after both acute and chronic administration, providing the first in vivo validation of CaMK1D as a target for diabetes therapeutics.

\section{INTRODUCTION}

The CaMK1 family of calmodulin-dependent kinases are widely expressed including in hepatocytes, endothelia, immune cells, and the CNS. ${ }^{1,2}$ There are four CaMK1 isoforms with high similarity in the kinase domain, especially the ATP binding site, but that differ in their overall structure and tissue distribution.

Single-nucleotide polymorphisms in the CaMK1D locus are associated with increased incidence of diabetes in a large number of genome-wide association studies (GWAS). ${ }^{3-6}$ While these variations are noncoding, it has been demonstrated that the diabetes-associated polymorphism rs11257655 increases FOXA1 transcription factor binding and thereby increases CaMK1D protein expression in multiple cell models. ${ }^{7}$ A direct role for CaMK1D in glucose processing has been observed following knock-down of commonly observed GWAS-identified proteins in primary human hepatocytes. ${ }^{8}$ In this model, treatment with CaMK1D siRNA results in loss of nuclear translocation of the established diabetes target CRTC2/ TORC $2^{9-11}$ and is associated with decreased gluconeogenesis and increased glycogen deposition.

Increased CaMK1D expression is also implicated in triplenegative breast cancer (TNBC). Large-scale genomic/transcriptomic analyses of breast tumors indicate that gains at the 10 p13 locus, which spans the CaMK1D gene, are observed in $80 \%$ of TNBC tumors ${ }^{12}$ with high occurrence in estrogen receptor-negative and TNBC tumors of younger patients. ${ }^{13}$ In a separate study, biopsies from 172 breast cancer patients showed

Received: January 21, 2020

Published: May 20, 2020 
Table 1. Structure-Activity Relationships of Pyrimidine Amides ${ }^{b}$

\begin{tabular}{|c|c|c|c|c|c|c|c|c|c|c|}
\hline \multirow[b]{2}{*}{ 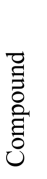 } & \multirow[b]{2}{*}{$\mathrm{R}_{1}$} & \multirow[b]{2}{*}{$\mathrm{R}_{2}$} & \multirow[b]{2}{*}{ 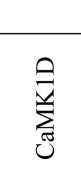 } & \multicolumn{3}{|c|}{$T_{\mathrm{m}}$ shift $\left({ }^{\circ} \mathrm{C}\right)$} & \multirow[b]{2}{*}{ 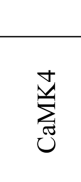 } & \multicolumn{3}{|c|}{$\mathrm{IC}_{50}(\mu \mathrm{M})$} \\
\hline & & & & $\underset{n}{x}$ & $\frac{a}{a}$ & $\frac{a}{\frac{0}{0}}$ & & $\begin{array}{l}\overrightarrow{\underline{J}} \\
\text { D }\end{array}$ & 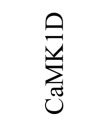 & 紊 \\
\hline 1 & $\mathrm{H}$ & HN & $\begin{array}{c}5.44 \\
(0.58)\end{array}$ & $\begin{array}{c}7.51 \\
(0.09)\end{array}$ & $\begin{array}{c}4.05 \\
(0.29)\end{array}$ & $\begin{array}{c}3.4 \\
(0.44)\end{array}$ & $\begin{array}{c}1.34 \\
(0.28)\end{array}$ & $\begin{array}{c}0.11 \\
(0.25)\end{array}$ & $\begin{array}{c}0.456^{a} \\
0.432 \\
(0.084)\end{array}$ & $0.007^{a}$ \\
\hline 2 & $\mathrm{Me}$ & & $\begin{array}{l}0.12 \\
(0.3)\end{array}$ & - & $\begin{array}{c}1.36 \\
(0.16)\end{array}$ & $\begin{array}{c}-0.27 \\
(0.39)\end{array}$ & $\begin{array}{c}-0.18 \\
(0.18)\end{array}$ & $\begin{array}{c}-0.53 \\
(0.15)\end{array}$ & - & - \\
\hline 3 & $\mathrm{H}$ & & $\begin{array}{l}7.35 \\
(0.4)\end{array}$ & $\begin{array}{c}5.13 \\
(0.17)\end{array}$ & $\begin{array}{c}4.48 \\
(0.13)\end{array}$ & $\begin{array}{c}0.84 \\
(0.13)\end{array}$ & $\begin{array}{c}2.13 \\
(0.21)\end{array}$ & $\begin{array}{c}0.10 \\
(0.07)\end{array}$ & $\begin{array}{c}0.851 \\
(0.160)\end{array}$ & - \\
\hline 4 & $\mathrm{H}$ & & $\begin{array}{c}2.43 \\
(0.08)\end{array}$ & - & $\begin{array}{c}2.70 \\
(0.27)\end{array}$ & $\begin{array}{c}0.70 \\
(0.16)\end{array}$ & $\begin{array}{c}3.36 \\
(0.08)\end{array}$ & $\begin{array}{c}0.11 \\
(0.14)\end{array}$ & $3.49^{a}$ & - \\
\hline 5 & $\mathrm{H}$ & & $\begin{array}{c}4.68 \\
(0.11)\end{array}$ & - & $\begin{array}{c}3.45 \\
(0.31)\end{array}$ & $\begin{array}{c}0.76 \\
(0.19)\end{array}$ & $\begin{array}{l}2.21 \\
(0.1)\end{array}$ & $\begin{array}{c}0.08 \\
(0.23)\end{array}$ & - & - \\
\hline 6 & $\mathrm{H}$ & & $\begin{array}{c}9.84 \\
(0.17)\end{array}$ & $\begin{array}{c}8.59 \\
(0.34)\end{array}$ & $\begin{array}{c}6.69 \\
(0.11)\end{array}$ & $\begin{array}{c}2.31 \\
(0.13)\end{array}$ & $\begin{array}{c}4.94 \\
(0.08)\end{array}$ & $\begin{array}{c}1.08 \\
(0.04)\end{array}$ & $\begin{array}{c}0.485 \\
(0.017)\end{array}$ & - \\
\hline 7 & $\mathrm{H}$ & & $\begin{array}{c}6.84 \\
(0.07)\end{array}$ & $\begin{array}{c}6.82 \\
(0.39)\end{array}$ & $\begin{array}{c}4.63 \\
(0.03)\end{array}$ & $\begin{array}{c}1.70 \\
(0.12)\end{array}$ & $\begin{array}{c}3.36 \\
(0.14)\end{array}$ & $\begin{array}{c}0.95 \\
(0.05)\end{array}$ & $\begin{array}{c}1.35 \\
(0.018)\end{array}$ & - \\
\hline 8 & $\mathrm{H}$ & & $\begin{array}{c}10.5 \\
(0.04)\end{array}$ & $\begin{array}{c}9.05 \\
(0.36)\end{array}$ & $\begin{array}{c}7.01 \\
(0.01)\end{array}$ & $\begin{array}{c}2.50 \\
(0.16)\end{array}$ & $\begin{array}{c}5.09 \\
(0.15)\end{array}$ & $\begin{array}{c}1.1 \\
(0.08)\end{array}$ & $\begin{array}{c}0.179^{a} \\
0.186 \\
(0.027)\end{array}$ & $0.087^{a}$ \\
\hline
\end{tabular}

${ }^{a}$ Compounds tested at Reaction Biology, $n=1 .{ }^{b}$ All data represent mean of at least $n=3$ independent experiments with standard deviation in parentheses, unless otherwise noted.

significant gains at the 10 p13 locus among basal-like tumors, leading to CaMK1D overexpression at transcriptional and protein levels. ${ }^{14}$ When expressed in nontumorigenic mammary epithelial cells (MCF10A), CaMK1D was found to lead to transformation, increasing proliferation and inducing a mesenchymal-like phenotype. ${ }^{14}$ Mouse models also corroborate the effect of overexpressing CaMK1D on altered cell proliferation and apoptosis. $^{15}$

Despite the emergence of CaMK1D as a potentially important therapeutic target, there are no known selective CaMK1 inhibitors. We therefore sought to develop potent and selective inhibitors of this class of kinases for use in target validation experiments, ahead of further translational studies.

\section{RESULTS AND DISCUSSION}

Compound $\mathbf{1}$ and derivatives thereof have received significant attention as inhibitors of spleen tyrosine kinase (SYK) and may have utility in the treatment of autoimmune disease or lymphomas. ${ }^{16-19}$ Previously published selectivity data shows compound 1 to have inhibitory activity against CaMK1D, ${ }^{20}$ and as such we selected this as the basis for a structure-based drug discovery campaign, with the aim of improving the potency and selectivity of compounds from this series toward CaMK1D. We initially examined the compound-induced shift in the thermal denaturation midpoint $\left(T_{\mathrm{m}}\right)$ of a small panel of kinases, in order to allow rapid quantification of the binding to both CaMK1D and off-target kinases (Table 1). Initial chemical efforts focused on alterations in the primary amide and amine regions, resulting in compounds 2-6, which demonstrate comparatively steep structure-activity relationships when either the primary amide or primary amine are substituted. Substitution of the secondary amine to give compound 3 is well tolerated and results in an apparent improvement in kinase selectivity, with further derivatization leading to compound $\mathbf{6}$, which demonstrated a higher $T_{\mathrm{m}}$ shift against CaMK1D and improved selectivity relative to earlier compounds. Separation of the enantiomers of this compound led to compounds 7 and 8 , the latter of which has previously been reported as a SYK inhibitor ${ }^{17}$ but has higher activity against CaMK1D than its enantiomer and demonstrates a more favorable activity profile relative to compounds $\mathbf{1}$ and $\mathbf{2}$ in both $T_{\mathrm{m}}$ and enzymatic assays.

Based on these results, we evaluated the pan-kinome selectivity of 8 in a competitive binding assay at $1 \mu \mathrm{M}$, which demonstrated a somewhat targeted profile. CaMK1D and SYK are among the 11 wild-type kinases inhibited by $>90 \%$ in this 
format, supported by subsequent enzymatic selectivity data against selected targets (Figure 1 and SI).

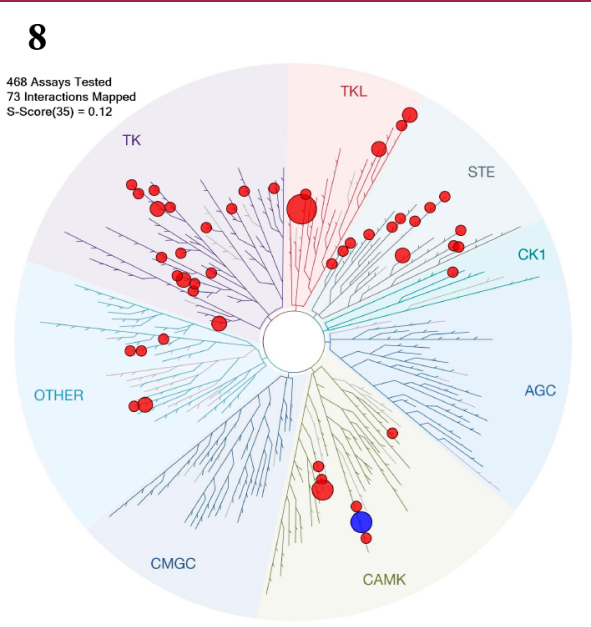

\begin{tabular}{|c|c|c|}
\hline Kinase & $\begin{array}{l}\% \text { residual probe } \\
\text { binding at } 1 \mu \mathbf{M}^{a}\end{array}$ & $\begin{array}{c}\text { Enzyme } \\
\text { IC }_{50}(\mu \mathrm{M})^{b}\end{array}$ \\
\hline RIPK4 & 0.9 & 0.092 \\
\hline CaMK1D & 2.0 & 0.179 \\
\hline PIM1 & 2.7 & 0.053 \\
\hline TAK1 & 5.7 & 0.356 \\
\hline CK2a & 6.5 & 9.131 \\
\hline MEK5 & 7.3 & 0.240 \\
\hline PIP5K1C & 8.1 & - \\
\hline CSF1R & 8.6 & 0.168 \\
\hline MLK3 & 8.9 & 0.052 \\
\hline BLK & 9.5 & 0.057 \\
\hline SYK & 9.6 & 0.087 \\
\hline
\end{tabular}

Figure 1. Selectivity data against selected wild-type kinases for compound 8. ${ }^{a}$ Compounds tested at Eurofins DiscoverX, $n=1$. ${ }^{b}$ Compounds tested at Reaction Biology, $n=1$.

As expected the CaMK1D-bound crystal structure of compound 8 (Figure 2) shows that the compound binds at the ATP binding site in a type- 1 fashion. A comparison of the binding mode of related compounds in SYK (e.g., PDB: 4RX9) demonstrated a slight shift in binding mode resulting from differences in the conformation of the loop at residues 163-165 (corresponding to 510-512 in SYK) as well as a flip in the orientation of the aniline meta-substituent in CaMK1D to occupy a pocket adjacent to $\mathrm{L} 100$ at the edge of the hinge region. The L100 pocket appears significantly larger in CaMK1D than the majority of the observed off-targets where structural data was available. In addition, the second meta region that is not utilized by 8 is close to the potentially flexible side chain of E105. We hypothesized that flipping of the orientation of the aniline allows the ligand to avoid the L100 pocket when binding to some offtarget kinases. This led to the design of compound 9 that removes this ambiguous binding mode by occupying both the L100 and E105 regions.

This bis-meta substitution pattern was well tolerated by CaMK1D when assessed by $T_{\mathrm{m}}$ shift and resulted in a significant decrease in the binding to off-targets including SYK (Table 2). Further SAR studies identified that a wide range of functional groups can be tolerated at the L100 pocket, with introduction of groups with a wide range of lipophilicity and bonding potential able to maintain or even enhance binding and selectivity (Table 2).

The binding affinity and selectivity for CaMK1D were further improved by combining these structural features in symmetrical and unsymmetrical bis-meta substituted anilines, especially those containing substituents that place electron density above and below the aniline ring plane. The clearest example of this is compound 14, which is too lipophilic to be a useful lead compound but nonetheless exhibits a very high $T_{\mathrm{m}}$ shift with CaMK1D and negligible off target binding. Evaluation of 14 in pan-kinome selectivity assay reveals highly specific binding to CaMK1D and the closely related CaMK1A and CaMK1B, again supported by enzymatic evaluation (Figure 3 and SI).

Our hypothesis is that the disconnect between the apparent high binding of 14 observed by $T_{\mathrm{m}}$ shift and the competitive binding assay at DiscoveRx, compared to the lower activity in competitive inhibition assays, relate to its poor physiochemical properties, which may lead to compound losses during serial dilution.

Despite the issues with properties in this specific example, we believed 14 demonstrated the potential to achieve high selectivity in this series and therefore sought to combine this selectivity with improved potency and physical properties by exploiting the wide SAR scope at the aniline meta positions. Subsequent evaluation of a wide range of aniline substituents

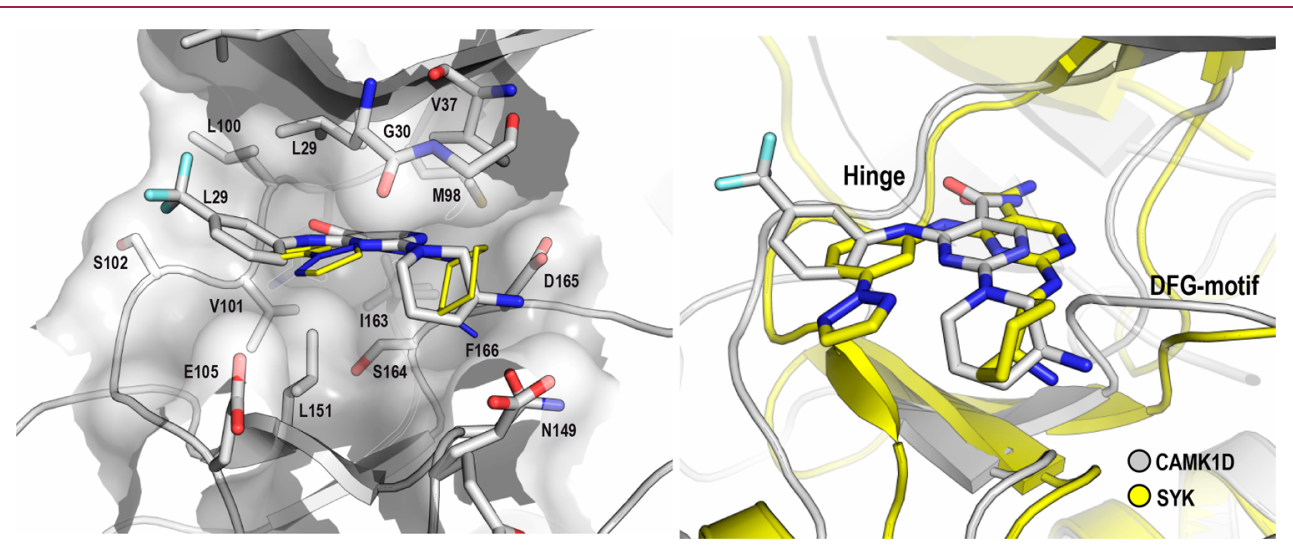

Figure 2. Compound 8 bound to CaMK1D (6T6F, white) and overlay with related SYK structure (4RX9, yellow). Important residues and inhibitors are shown in stick representation. For better visibility, the P-Loop has been made transparent. 
Table 2. Effects of Varying Aniline Substitution on Potency and Selectivity ${ }^{a}$

\begin{tabular}{|c|c|c|c|c|c|c|c|c|}
\hline \multirow[b]{2}{*}{ compd } & \multirow[b]{2}{*}{$\mathrm{R}_{3}$} & \multicolumn{6}{|c|}{$T_{\mathrm{m}}$ shift $\left({ }^{\circ} \mathrm{C}\right)$} & \multirow[b]{2}{*}{ CaMK1D enzyme $\mathrm{IC}_{50}(\mu \mathrm{M})$} \\
\hline & & CaMK1D & SYK & DAPK1 & CK2a & $\mathrm{ABL}$ & PIM1 & \\
\hline 8 & $3-\mathrm{CF}_{3}$ & $10.5(0.04)$ & $9.05(0.36)$ & $5.92(0.45)$ & $3.77(0.12)$ & $5.02(0.36)$ & $8.32(0.28)$ & $0.186(0.027)$ \\
\hline 9 & $3,5-\mathrm{diCF}_{3}$ & $13.3(0.09)$ & $4.13(0.57)$ & $6.07(0.06)$ & $5.89(0.1)$ & $3.88(0.24)$ & $3.98(0.05)$ & $0.455(0.451)$ \\
\hline 10 & $3-t \mathrm{Bu}$ & $9.61(0.16)$ & $4.58^{b}(0.33)$ & $3.02(0.09)$ & $3.02(0.56)$ & $2.27(0.22)$ & $2.09(0.44)$ & $0.277^{c}(0.053)$ \\
\hline 11 & $3-\mathrm{SO}_{2} \mathrm{Me}$ & $7.85(0.09)$ & $5.23(0.18)$ & $4.21(0.09)$ & $5.11(0.02)$ & $5.33(0.09)$ & $1.78(0.65)$ & $0.101(0.07)$ \\
\hline 12 & $3-\mathrm{Ph}$ & $11.9(0.26)$ & $9.32(0.29)$ & $4.81(0.11)$ & $3.79(0.01)$ & $4.5(0.26)$ & $4.96(0.06)$ & $0.047(0.026)$ \\
\hline 13 & 3-(2-cyanoiPr) & $7.76(0.24)$ & $5.00(0.28)$ & $3.32(0.39)$ & $9.51(0.19)$ & $2.85(0.28)$ & $1.3(0.2)$ & $0.096(0.05)$ \\
\hline
\end{tabular}

${ }^{a}$ All data represent mean of at least $n=3$ independent experiments with standard deviation in parentheses. ${ }^{b}$ Measured on racemic compound. ${ }^{c} n=$ 2 .

generally validated our hypothesis that "bulky" substituents are favored for both potency and selectivity.

This work led to compounds 15-18, which show good binding and selectivity in both $T_{\mathrm{m}}$ and enzymatic assays. Selected compounds were assessed for their ability to inhibit autophosphorylation of CaMK1D at activation loop residues serine 179 and threonine 180 in overexpressing MDA-MB-231 cells. This data demonstrated that the inhibitors have limited cell drop-off for compounds with no additional $\mathrm{H}$-bond donors or basic centers (Table 3). Pan-kinome screening data on 18 (Figure 4) shows that the high selectivity of 14 can be maintained in compounds with more favorable physicochemical properties, with enzymatic data on identified off-targets demonstrating $>150$-fold greater activity against CaMK1D than all non-CaMK1 kinases.

The in vitro pharmacokinetic profile of $\mathbf{1 8}$ reveals generally favorable properties with high solubility, low metabolism, and moderately high plasma protein binding (PPB), but low permeability with some evidence of efflux in the $\mathrm{CaCo} 2$ model (Table 5). This low permeability does not appear to impact either cellular activity or oral pharmacokinetics, where 18 shows good bioavailability in mice and rats despite moderately high clearance.

The oral pharmacokinetic profile of $\mathbf{1 8}$ in mice scaled well at doses up to $100 \mathrm{mg} / \mathrm{kg}$, and the PPB-adjusted cover over cellular $\mathrm{IC}_{50}$ observed suggested that this compound may be suitable for in vivo target validation studies (Figure 5).

In order to improve the potential utility of these compounds, we sought to identify a lead compound with improved potency and reduced clearance in order to allow for greater cover in the in vivo experiments at reduced doses. In common with 18, a large number of compounds from this series demonstrated high solubility, low $\mathrm{A}-\mathrm{B} /$ high $\mathrm{B}-\mathrm{A} \mathrm{CaCo} 2$ permeability and moderate to low metabolism in mouse microsome and hepatocyte assays. However, the in vivo clearance of the compounds was often greater than estimated liver blood flow, suggesting that hepatic metabolism is not the key driver of clearance in mouse.

A more detailed evaluation of the in vivo pharmacokinetics of 18 revealed a similar picture. Despite its high in vivo clearance, metabolite identification studies on rat ex vivo plasma samples reveal only low levels of metabolites, resulting from oxidation, acetylation, or amide hydrolysis (potentially subsequent to acetylation), while analysis of urine collected from 18 dosed rats reveals that renal excretion of unchanged drug at least partially contributes to clearance.

Despite the poor predictivity of the in vitro pharmacokinetic assays, optimization of the aniline region of the compounds was continued, relying on in vivo studies to distinguish compounds that showed suitable in vitro activity profiles. This work led to the finding that compounds containing 4-pyridyl substituents such as that seen in 19 exhibited retained or enhanced activity in CaMK1D enzyme and cell assays with similar selectivity (Figure 6, Table 4) but reduced in vivo clearance. Examination of the structure activity relationships around this structural change revealed similar SAR to that observed with the anilines. Our hypothesis is that the pyridyl nitrogen is protonated in the bound state, supported by experimental data revealing that 19 is dibasic, with $\mathrm{p} K_{\mathrm{a}}$ values of 8.7 and 7.5 for the primary amine and pyridine, respectively.

The increased potency and higher in vivo blood concentrations seen with 19 result in significantly improved free cover over the cellular $\mathrm{IC}_{50}$ in mouse (Figure 7 ), and consistent with the low $\mathrm{CaCo} 2 \mathrm{~A}-\mathrm{B} /$ high $\mathrm{B}-\mathrm{A}$ seen with this compound, the free plasma to brain ratio is $\leq 0.01$ at all time points to $24 \mathrm{~h}$. The compound retains high pan-kinome selectivity; however the move to secondary (i.e., isopropyl) substituents does result in a reduction in selectivity over MEK5 in both affinity and biochemical assays. These findings are reflected in the CaMK1D bound crystal structures of compounds 18 and 19 (Figure 8), which show the isopropyl groups in 19 occupying a low-energy conformation with the methyl groups out of the plane of the aryl ring, potentially avoiding unfavorable interactions with the protonated pyridine.

As expected from the high active site homology in the CaMK1 family, both 18 and 19 show limited selectivity between CaMK1A, CaMK1B, CaMK1D, and CaMK1G. More detailed secondary pharmacology screening with 18 and 19 reveals some evidence of hERG and CYP450 inhibition (Table 5) with the compounds demonstrating $\sim 300$-fold selectivity over hERG based on cellular $\mathrm{IC}_{50}$.

Initial evaluation of the in vivo efficacy of these inhibitors was conducted in mice with diet-induced obesity (DIO mice), which demonstrate impaired glucose control mediated by reduced sensitivity to insulin. Compound $\mathbf{1 8}$ was selected for these studies due to its high kinome selectivity, with sampling 
14

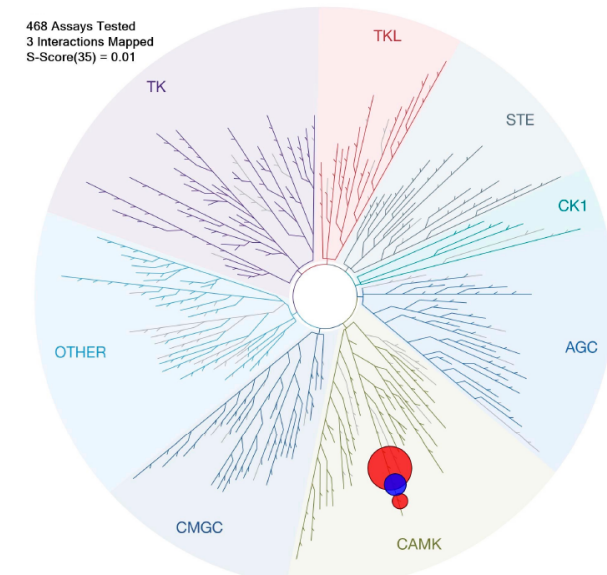

\begin{tabular}{cccc} 
Kinase & $\begin{array}{c}\boldsymbol{T}_{\mathbf{m} \text { shift }} \\
\left({ }^{\circ} \mathbf{C}\right)\end{array}$ & $\begin{array}{c}\text { \% residual } \\
\text { probe } \\
\text { binding at } \\
\mathbf{1} \boldsymbol{\mu} \mathbf{M}^{a}\end{array}$ & $\begin{array}{c}\text { Enzyme } \\
\mathbf{I C}_{50} \\
(\boldsymbol{\mu M})^{b}\end{array}$ \\
\hline CaMK1D & $\begin{array}{c}12.4 \\
(0.07)\end{array}$ & 1.4 & 0.399
\end{tabular}

\begin{tabular}{cccc} 
CaMK1B & - & 0.0 & - \\
CaMK1A & - & 8.8 & - \\
& 1.13 & 81 & - \\
DAPK1 & $(0.03)$ & & - \\
& -0.03 & 100 & - \\
CK2a & $(0.08)$ & & - \\
PIM1 & -0.43 & 100 & $>10$ \\
MEK5 & $(0.93)$ & 95 & $>10$ \\
MLK3 & - & 77 & - \\
SYK & 0.37 & 82 & $(0.27)$ \\
\hline
\end{tabular}

Figure 3. Selectivity data against selected wild-type kinases for compound 14. $T_{\mathrm{m}}$ shift data represents mean of at least $n=3$ independent experiments with standard deviation in parentheses, see Supporting Information for experimental details. ${ }^{a}$ Compounds tested at Eurofins DiscoverX, $n=1 .{ }^{b}$ Compounds tested at Reaction Biology, $\mathrm{n}=$ 1.

revealing slightly higher exposure in DIO mice relative to earlier pharmacokinetic studies (Figure 5) and no significant changes in exposure on repeat dosing for 14 days at $25 \mathrm{mg} / \mathrm{kg}$. DIO mice treated with a single dose of 25 or $50 \mathrm{mg} / \mathrm{kg} 18$ (in 1:9 DMSO/ $20 \%$ aqueous 2 -hydroxypropyl- $\beta$-cyclodextrin) $4 \mathrm{~h}$ prior to an oral glucose tolerance test (OGTT) show improved glucose control and increased insulin sensitivity relative to vehicle controls (Figure 9A), with no significant difference in effect between the $25 \mathrm{mg} / \mathrm{kg}$ and $50 \mathrm{mg} / \mathrm{kg}$ dose groups. Repeat administration of 18 twice daily for 14 days (in 1:9 DMSO/20\% aqueous 2 -hydroxypropyl- $\beta$-cyclodextrin on days $1-6$, and $1 \%$ methyl cellulose on days 7-14) resulted in reduced baseline glucose and insulin levels, as well as reduced peak glucose levels following OGTT. While there was no effect on glucose AUCB2 in this experiment, the improvement in apparent insulin sensitivity was maintained, and the overall profile was similar to the positive control liraglutide, which demonstrated a similar profile to that expected based on previous data. Unfortunately repeat dosing of $50 \mathrm{mg} / \mathrm{kg} 18$ was not tolerated due to bloating of the gastrointestinal tract (resulting in change of vehicle in the $25 \mathrm{mg} / \mathrm{kg}$ group at day 7); however this was not observed in subsequent tolerability studies with other compounds at significantly higher exposure/free cover. For example, 19 has been dosed at $40 \mathrm{mg} / \mathrm{kg}$ once daily (uid; in 50:45:5 PEG400/ water/ethanol) for 21 days in NGS mice with no observable adverse effects, suggesting that the GI effects seen with $\mathbf{1 8}$ are unlikely to be target related.

\section{CHEMISTRY}

Compounds $\mathbf{1}$ and $\mathbf{2}$ are known compounds and were prepared using the previously reported synthesis. ${ }^{16}$ Analogues $3-8$ were prepared from ethyl 2,4-dichloropyrimidine-5-carboxylate 20 via the 2-HOBt pyrimidine intermediate $\mathbf{2 1}$, which was prepared as previously described, ${ }^{16}$ by displacement of the 2 -HOBt by the appropriate Boc-protected amine and Boc removal under acidic conditions (Scheme 1).

To explore the aniline component, the tail was fixed to the (S)-3-aminopiperidine and a new synthetic strategy was sought to provide more rapid access to analogues with varied aniline substituents. The commercially available 2,4-dichloropyrimidine-5-carboxamide 22 allows formation of the final products in a typically 3 -step process, by sequential displacement using the aniline followed by protected (S)-3-aminopiperidine and final acidic deprotection (Scheme 2). The synthesis can be abbreviated by utilizing excess unprotected $(S)$-3-aminopiperidine directly in the second stage, with the increased nucleophilicity of the cyclic secondary amine resulting in $<1 \%$ formation of the product resulting from reaction at the primary amine. In general, this approach complicates the purification of the final compounds and as such has not been extensively used but may be useful when introducing acid-sensitive anilines.

The route outlined in Scheme 2 provided ready access to compounds $9-14$ by utilizing commercially available anilines in stage 1. Subsequent synthetic effort focused on preparation of anilines designed to develop the emerging SAR in this series. The symmetrical anilines $\mathbf{2 7}$ and $\mathbf{2 8}$ were initially synthesized by Suzuki reaction on dibromo precursors 23 and 24; however it was later found that use of the nitro derivatives 25 and 26 results in a slightly cleaner reaction and easier purification, without adding extra steps as the nitro group and carbon-carbon double bonds are reduced in a single stage by heterogeneous hydrogenation (Scheme 3).

In order to prepare the mixed ${ }^{t} \mathrm{Bu} /$ methylsulfone aniline 34 , the commercially available nitro compound $\mathbf{2 9}$ was treated with chlorosulfonic acid in chloroform at reflux to afford the sulfonyl chloride 30, which was reduced to the thiol $\mathbf{3 1}$ with triphenyl phosphine in refluxing toluene. Alkylation of $\mathbf{3 1}$ with methyl iodide provided the methyl sulfide 32, which was oxidized with $m$-CPBA to the corresponding sulfone 33 , before nitro group reduction by heterogeneous hydrogenation to provide aniline 34 (Scheme 4).

The cyanoisopropyl anilines used in compounds $\mathbf{1 7}$ and $\mathbf{1 8}$ were prepared from 3,5-dibromoaniline 27 by bis-benzylation to give 35 followed by treatment with potassium 2-cyano-2methylpropanoate and palladium catalyst ${ }^{21}$ to afford a separable mixture of the symmetrical aniline 36 and partially reacted bromo derivative $\mathbf{3 7}$. Compound $\mathbf{3 7}$ was submitted to a second Suzuki coupling to afford intermediate 38. Debenzylation of 36 
Table 3. Effects of Varying Substitution of Bis-meta-Substituted Anilines on Potency and Selectivity

\begin{tabular}{|c|c|c|c|c|c|c|c|c|c|c|}
\hline \multirow[b]{2}{*}{ compd } & \multirow[b]{2}{*}{$\mathrm{R}_{3}$} & \multirow[b]{2}{*}{$\mathrm{R}_{3}^{\prime}$} & \multicolumn{6}{|c|}{$T_{\mathrm{m}}$ shift $\left({ }^{\circ} \mathrm{C}\right)$} & \multicolumn{2}{|c|}{$\mathrm{CaMK} 1 \mathrm{D} \mathrm{IC}_{50}(\mu \mathrm{M})$} \\
\hline & & & CaMK1D & SYK & DAPK1 & CK2a & $\mathrm{ABL}$ & PIM1 & enzyme & cell \\
\hline 15 & $i \operatorname{Pr}$ & $i \operatorname{Pr}$ & $11.9(0.15)$ & $8.20(0.37)$ & $4.65(0.19)$ & $4.05(0.07)$ & $5.95(0.17)$ & $0.62(0.32)$ & $0.115(0.051)$ & $0.285^{b}(0.013)$ \\
\hline 16 & $t \mathrm{Bu}$ & $\mathrm{SO}_{2} \mathrm{Me}$ & $11.8(0.25)$ & $0.87(0.38)$ & $3.83(0.19)$ & $1.85(0.16)$ & $1.09(0.06)$ & $0.94(0.46)$ & $0.027(0.005)$ & $0.028^{b}(0.011)$ \\
\hline 17 & 2-cyano-iPr & $\mathrm{Ph}$ & $15.9(0.13)$ & & $4.8(0.2)$ & $-0.21(0.37)$ & $1.95(0.02)$ & $1.11(0.14)$ & $0.022(0.009)$ & $0.019^{b}(0.001)$ \\
\hline 18 & 2-cyano-iPr & 2-cyano-iPr & $11.5(0.17)$ & & $3.46(0.23)$ & $0.56(0.16)$ & $0.27(0.16)$ & $0.81(0.27)$ & $0.031(0.003)$ & $0.008(0.002)$ \\
\hline
\end{tabular}

${ }^{a}$ All data represent mean of at least $n=3$ independent experiments with standard deviation in parentheses, unless otherwise noted. ${ }^{b} n=2$.

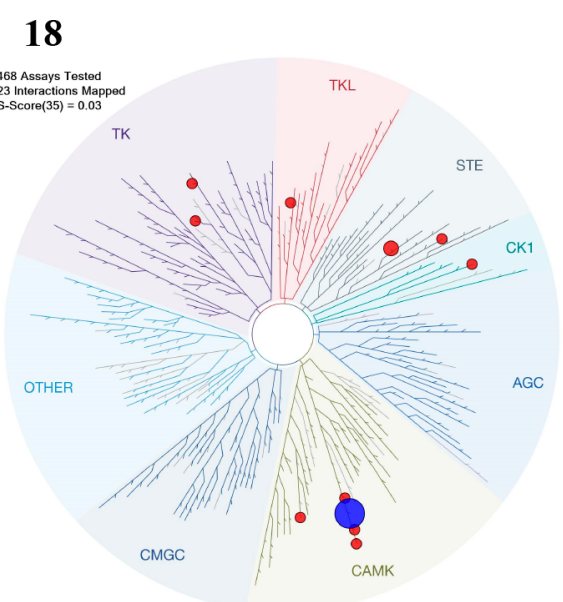

\begin{tabular}{|c|c|c|}
\hline Kinase & $\begin{array}{c}\text { \% residual } \\
\text { probe binding at } \\
1 \mu \mathrm{M}^{a}\end{array}$ & $\mathbf{I C}_{50}(\mu \mathbf{M})^{b}$ \\
\hline CaMK1D & 0.9 & $0.026^{c}$ \\
\hline CaMK1B & 15 & $\begin{array}{c}0.011 \\
(<0.001)\end{array}$ \\
\hline CaMK1A & 16 & $\begin{array}{c}0.002 \\
(0.001)\end{array}$ \\
\hline PIP5K1C & 3.0 & $7.12^{c}$ \\
\hline MEK5 & 9.8 & $\begin{array}{c}7.68 \\
(0.547)\end{array}$ \\
\hline MLK3 & 95 & $\begin{array}{c}7.86 \\
(4.20)\end{array}$ \\
\hline
\end{tabular}

Figure 4. Selectivity data against selected wild-type kinases for compound 18. ${ }^{a}$ Compounds tested at Eurofins DiscoverX, $n=1$. ${ }^{b}$ Compounds tested at Reaction Biology, $n=2$ independent experiments with standard deviation in parentheses, except ${ }^{c} n=1$.

and 39 by heterogeneous hydrogenation provided the anilines 38 and 40 (Scheme 5).

\section{EXPERIMENTAL SECTION}

$T_{\mathrm{m}}$ Shift Assays. Thermal melting experiments were carried out using a Stratagene Mx3005p Real Time PCR machine (Agilent Technologies). Proteins were buffered in $10 \mathrm{mM}$ HEPES, pH 7.5, 500 $\mathrm{mM} \mathrm{NaCl}$ and assayed in a 96-well plate at a final concentration of $2 \mu \mathrm{M}$ in a $20 \mu \mathrm{L}$ volume. Compounds were added at a final concentration of $10 \mu \mathrm{M}$ (final DMSO concentration was $0.025 \%$ ). SYPRO Orange (Molecular Probes) was added as a fluorescence probe at a dilution of 1:1000 (v/v). Excitation and emission filters for the SYPRO-Orange dye were set to 465 and $590 \mathrm{~nm}$, respectively. The temperature was raised with a step of $3{ }^{\circ} \mathrm{C}$ per minute from 25 to $96^{\circ} \mathrm{C}$, and fluorescence readings were taken at each interval. Experiments were performed in triplicate, and the observed temperature shifts, $\Delta T_{\mathrm{m}}^{\mathrm{obs}}$, were recorded as the difference between the transition midpoints of sample and reference wells containing protein without ligand in the same plate and determined by nonlinear least-squares fit, reported in ${ }^{\circ} \mathrm{C}$ as the mean of the values obtained from 3 independent repeats.

CaMK1D ADP GLO Assay. Test compounds were prepared in $100 \% \mathrm{DMSO}$, and $12 \mathrm{~nL}$ was dispensed to individual wells of a multiwell plate (PerkinElmer, catalog no. 6007290). A reaction mixture containing full length His tagged CaMK1D (Fisher Scientific, PR6770A), calmodulin (Merck, 208694), and autocamtide-2 (SignalChem, A15-58) was prepared in assay buffer composed of $50 \mathrm{mM}$ Tris$\mathrm{HCl}, \mathrm{pH} 7.5,10 \mathrm{mM} \mathrm{MgCl} 2,0.1 \mathrm{CaCl}_{2}$ and $2 \mathrm{mM}$ DTT. A $7.88 \mu \mathrm{L}$ portion of reaction mixture was added to each well to give final assay concentrations: $3 \mathrm{nM}$ CaMK1D, $1 \mu \mathrm{M}$ calmodulin, and $125 \mu \mathrm{M}$ autocamtide-2. Plates were centrifuged at $300 \mathrm{rpm}$ for $30 \mathrm{~s}$ and incubated for $15 \mathrm{~min}$ at $25^{\circ} \mathrm{C}$. The enzyme reaction was initiated by the addition of $4 \mu \mathrm{L}$ of $30 \mu \mathrm{M}$ ATP solution to give a final assay concentration of $10 \mu \mathrm{M}$. Plates were centrifuged at $300 \mathrm{rpm}$ for $30 \mathrm{~s}$ and then incubated at $25{ }^{\circ} \mathrm{C}$ for $2 \mathrm{~h}$. ADP-Glo (Promega, catalog no. V9102) was prepared according to manufacturer's instructions and equilibrated to room temperature, shielded from light. Addition of 12 $\mu \mathrm{L}$ of ADP-Glo reagent was made to terminate the kinase reaction and deplete residual ATP. Plates were centrifuged at $300 \mathrm{rpm}$ for $30 \mathrm{~s}$ and then incubated at $25{ }^{\circ} \mathrm{C}$ for $1 \mathrm{~h}$. Following ATP depletion, $24 \mu \mathrm{L}$ of ADP-Glo substrate was added to convert ADP to ATP and initiate a luciferase/luciferin chemiluminescent reaction. Plates were centrifuged at $300 \mathrm{rpm}$ for $30 \mathrm{~s}$ and then incubated at $25^{\circ} \mathrm{C}$ for $30 \mathrm{~min}$, shielded from light. After $30 \mathrm{~min}$, plates were read with the EnVision Multilabel Plate Reader, using Luminescence 700 . Compound $\mathrm{IC}_{50}$ was determined using a 4-parameter equation and reported as the geometric mean of the $\mathrm{IC}_{50}$ values obtained from 3 independent repeats.

pCaMK1D Cell Assay. MDA-MB-231 cells were purchased from the ATCC and routinely cultured in DMEM containing $10 \%$ FCS and 5 $\mathrm{U} / \mathrm{mL}$ penicillin/streptomycin (Gibco). MDA-MB-231-HA-CaMK1D cells were established by infecting MDA-MB-231 cells with modified pLVx-HA-CaMK1D lentivirus. Transduced cells were selected in media containing puromycin $(2 \mu \mathrm{g} / \mathrm{mL})$, and expression of CamK1D was verified by Western blotting using rabbit anti-CamK1D mAb ([EPR3536(2)] (ab172618), used at $0.1 \mathrm{mg} / \mathrm{mL})$. Custom made anti-pCamK1D (Ser179, Thr180) polyclonal antibodies were prepared by LifeTein (Hillsborough, NJ, USA), immunizing MEGKGDVM(pS)(pT)ACGTPGYVA peptide, and verified in a series of Western blotting experiments. MDA-MB-231-HA-CaMK1D cells were cultured in DMEM Glutmax (31966-021, ThermoFisher) containing 10\% fetal 


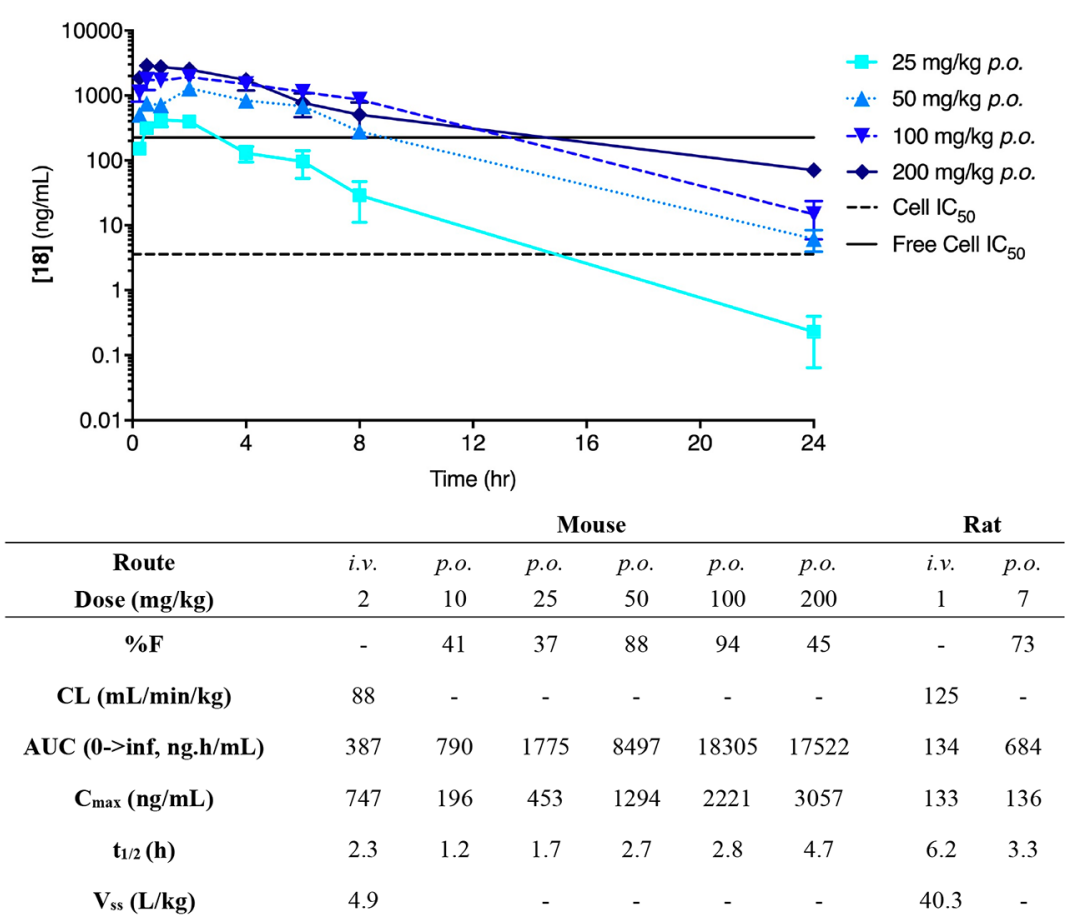

Figure 5. In vivo pharmacokinetic profile of 18 in male CD-1 mice (25-40 g) and male Crl:CD Sprague-Dawley rats (250-400 g) dosed in $10 \%$ DMSO/90\% hydroxypropyl- $\beta$-cyclodextrin $(20 \% \mathrm{w} / \mathrm{v}), n=3$ per group. Free cell $\mathrm{IC}_{50}$ was calculated by dividing measured cellular $\mathrm{IC}_{50}$ by free fraction in mouse plasma.

bovine serum (FBS) and $1 \%$ penicillin-streptomycin. For the assay, cells were seeded at $1.25 \times 10^{5}$ cells $/ \mathrm{mL}$ in 6-well plates and maintained at $37{ }^{\circ} \mathrm{C}$ in a humidified incubator with $5 \% \mathrm{CO}_{2}$ and $95 \%$ air for $48 \mathrm{~h}$. Then, cells were treated with compound for $4 \mathrm{~h}$ with a final DMSO concentration of $0.1 \%$; for each compound, an 11 -point serial dilution was used and DMSO was included as a control. Media was aspirated, and the cells were washed with PBS. Cells were lysed, supernatants were recovered by centrifugation at $13000 \mathrm{rpm}$, protein concentrations were measured, and equal amounts of total protein were separated by SDSPAGE. Proteins were transferred to PVDF membranes (Bio-Rad), which was followed by blocking for $1 \mathrm{~h}$ in $5 \%$ milk in TBS-T. Membranes were incubated overnight at $4{ }^{\circ} \mathrm{C}$ with primary antibody: anti-pCamK1D (Ser179, Thr180) (1:1000) or total CaMK1D (1:10000, ab172618, Abcam). Membranes were incubated with the corresponding HRP-conjugated secondary antibody (7074S, CST) for $1 \mathrm{~h}$. Specific bands were detected using the enhanced-chemiluminescence reagent (Clarity Western substrate, Bio-Rad) and the ChemiDoc MP Gel Imaging System (Bio-Rad), and \% change in pCAMK1D from control was calculated using a ratio of pCaMK1D to total CaMK1D bands. Compound $\mathrm{IC}_{50}$ was determined using a 4-parameter equation and reported as the geometric mean of the $\mathrm{IC}_{50}$ values obtained from 3 independent repeats.

Oral Glucose Tolerance Test after Acute and Chronic, Subacute (14 Day) Dosing. Male C57Bl/6J mice obtained from Charles River UK (Margate, Kent, UK) at 7-8 weeks of age were group housed for 16 weeks ( $n=3$ in each cage) on a normal light/dark cycle (lights on 07:00-19:00 h) with ad libitum access to a high fat diet (D12451 diet, $45 \%$ kcal as fat, $35 \%$ as carbohydrate; Research Diets, New Jersey, USA) and filtered water.

Acute Dosing Study. Animals were allocated to dosing groups (6 mice per group) such that groups were balanced as closely as possible for mean body weight. The day prior to the OGTT, all animals were deprived of food (but not water) beginning approximately 16:45. The following morning, the mice were dosed with vehicle or either $10 \mathrm{mg} /$ $\mathrm{kg}, 25 \mathrm{mg} / \mathrm{kg}$, or $50 \mathrm{mg} / \mathrm{kg} 18$ formulated in a vehicle of DMSO (10\% final volume) and $20 \%$ (2-hydroxypropyl)- $\beta$-cyclodextrin (90\% final volume) by the oral route (beginning at $08: 45$ ). Four hours after dosing, a blood sample was taken (B1), and 3 min later glucose was administered ( $2 \mathrm{~g} / \mathrm{kg}$ orally). Further blood samples were taken 10, 30, 60 , and 90 min after glucose administration. Between blood sampling, animals were returned to the home cage with free access to water (but not food). Blood samples (approximately $30 \mu \mathrm{L}$ ) were collected into lithium heparinized tubes (Sarstedt Microvette CB300LH), and plasma was separated by centrifugation to produce a single aliquot of plasma, which was frozen (approximately $-80^{\circ} \mathrm{C}$ ) and subsequently assayed for glucose (in duplicate; Thermoelectron Infinity glucose reagent TR15498) and insulin (single replicate; Alpco mouse ultrasensitive insulin kit 80, INSMSU-E10).

Chronic Dosing Study. Upon completion of the OGTT, all animals were singly housed with food provided as above for 2 weeks prior to the onset of the baseline phase of the chronic study. Upon single housing after the OGTT, mice were placed on a reverse-phase light-dark cycle (lights off 09:30-17:30). Following this period, the animals underwent a 5-day baseline phase where they were dosed twice daily with vehicle at approximately 08:45 and 16:45 each day. Toward the end of the baseline phase mice were reallocated to dosing groups ( 8 animals per group) such that groups within the study were balanced as closely as possible for body weight, food and water intake, and previous treatment. From day 1 onward, mice were dosed orally twice daily with $25 \mathrm{mg} / \mathrm{kg} 18$ formulated in a vehicle of DMSO (10\% final volume) and $20 \%$ (2-hydroxypropyl)- $\beta$-cyclodextrin ( $90 \%$ final volume) on days $1-6$ and $1 \%$ methyl cellulose at $5 \mathrm{~mL} / \mathrm{kg}$ on subsequent days or twice daily orally with vehicle alone or subcutaneously with $0.1 \mathrm{mg} / \mathrm{kg}$ liraglutide (Bachem) formulated in $\mathrm{pH} 7.4$ phosphate buffer solution. Oral dosing began at approximately 08:45 and 16:45, with subcutaneous dosing at 08:45 only. Dosing continued until the morning of day 14, when food was removed beginning at approximately 16:45. Approximately $16 \mathrm{~h}$ postfast, the animals were moved to a separate room maintained under normal lighting and dosed with vehicle or test compounds in the normal manner to a timed schedule $4 \mathrm{~h}$ prior to the administration of the glucose challenge $(2.0 \mathrm{~g} / \mathrm{kg}$ po). Blood samples were taken immediately prior to dosing (B1), immediately prior to glucose administration (B2), and $15,30,60$, and 90 min after glucose administration. All blood samples (approximately $30 \mu \mathrm{L}$ ) were taken in lithium heparin-coated tubes (Sarstedt CB300LH) and spun as soon as possible in a centrifuge. 


\section{9}

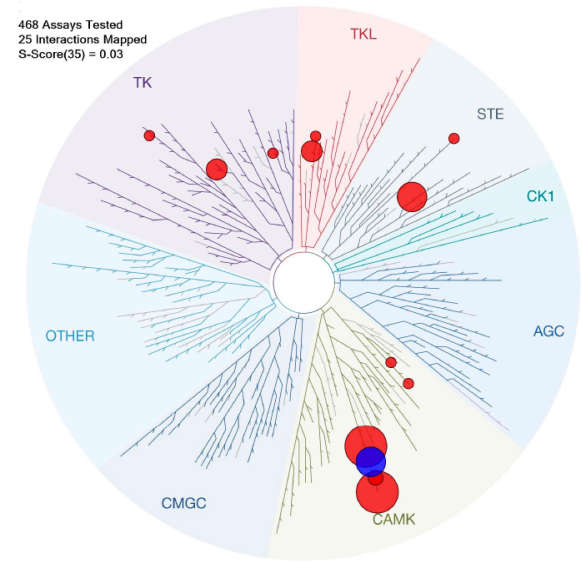

Compound 19

\begin{tabular}{|c|c|c|}
\hline \multirow[b]{2}{*}{ Kinase } & \multicolumn{2}{|c|}{ Compound 19} \\
\hline & $\begin{array}{c}\% \text { residual } \\
\text { probe binding } \\
\text { at } 1 \mu \mathbf{M}^{a} \\
\end{array}$ & $\begin{array}{c}\mathbf{I C}_{\mathbf{5 0}} \\
(\mu \mathbf{M})^{b}\end{array}$ \\
\hline CaMK1D & 0.9 & $0.008^{c}$ \\
\hline CaMK1B & 0 & $\begin{array}{c}0.003 \\
(<0.001)\end{array}$ \\
\hline CaMK1A & 0 & $\begin{array}{c}0.001 \\
(<0.001)\end{array}$ \\
\hline CaMK1G & 0 & $\begin{array}{c}0.001 \\
(<0.001)\end{array}$ \\
\hline PIP5K1C & 0 & $\begin{array}{c}11.2 \\
(8.50)\end{array}$ \\
\hline MEK5 & 0.95 & $\begin{array}{c}0.025 \\
(0.012)\end{array}$ \\
\hline RIPK4 & 4.5 & $\begin{array}{c}5.69 \\
(0.310)\end{array}$ \\
\hline MLK3 & 99 & $\begin{array}{c}2.75 \\
(2.05)\end{array}$ \\
\hline
\end{tabular}

Figure 6. Selectivity data against selected wild-type kinases for compound 19. ${ }^{a}$ Compounds tested at Eurofins DiscoverX, $n=1$. ${ }^{b}$ Compounds tested at Reaction Biology data, $n=2$ independent experiments with standard deviation in parentheses, except ${ }^{c} n=1$.

Plasma samples were stored frozen (approximately $-80{ }^{\circ} \mathrm{C}$ ) until determination of plasma glucose (in duplicate; Thermoelectron Infinity glucose reagent TR15498) and insulin (single replicate; Alpco mouse ultrasensitive insulin kit 80, INSMSU-E10). Plasma glucose and insulin data from the OGTTs were analyzed by robust regression with treatment as a factor and bleeding order and day 1 body weight as covariates. AUC for 0 to 60 (following single dose) and 0 to $90 \mathrm{~min}$ (following repeat dose) was calculated (as total AUC and AUC from baseline) by trapezoidal rule and analyzed by the same methodology. In all cases, this analysis was followed by multiple $t$ test comparisons to determine significant differences in both absolute levels and AUC from the vehicle group.

General Chemistry Experimental Methods. Commercially available and enantiomerically pure tert-butyl $(S)$-piperidin-3-ylcarbamate and tert-butyl $(R)$-piperidin-3-ylcarbamate were purchased from Carbosynth Ltd. (e.g., FB11271) and used as provided. All other commercially available starting materials, reagents, and solvents were purchased and used without further purification. The reactions were monitored by thin-layer chromatography ( 60 on aluminum sheets with F254) or by LCMS. LC data was obtained using a Waters ACQUITY UPLC PDA detector scanning between 210 and $400 \mathrm{~nm}$. Mass spectrometry data was acquired using a Waters ACQUITY QDa detector scanning in the positive $\left(\mathrm{ES}^{+}\right)$and negative $\left(\mathrm{ES}^{-}\right)$modes between $\mathrm{m} / z 100$ and 1000 . Separation of components was achieved using a Waters ACQUITY UPLC BEH C18 $1.7 \mu \mathrm{m}, 2.1 \mathrm{~mm} \times 50 \mathrm{~mm}$ column coupled to a Waters ACQUTY UPLC BEH C18 $1.7 \mu \mathrm{m}$ VanGuard precolumn, $2.1 \mathrm{~mm} \times 5 \mathrm{~mm}$. Columns were maintained at $40{ }^{\circ} \mathrm{C}$ throughout acquisition. Data was processed using MassLynx V4.1. Values of purity were obtained through analysis of the peak areas in the LC trace between 0.40 and $3.50 \mathrm{~min}$. Purity and identity of all tested compounds were established by a combination of mass spectrometry, HRMS, and NMR spectra as described below. Purification of isolated products was carried out by column chromatography in silica gel (particle size $40-63 \mu \mathrm{m}$, Merk) or medium pressure liquid chromatography (MPLC) on a CombiFlash Companion (Teledyne ISCO) with AquaGold prepacked reversephase C18 columns. Nuclear magnetic resonance (NMR) spectra were obtained on a Bruker Advance 400 or $500 \mathrm{MHz}$ spectrometer. Chemical shifts $(\delta)$ are reported in ppm using the residual signal of the deuterated solvent $\left(\mathrm{MeOD}-d_{4}, \mathrm{CDCl}_{3}, \mathrm{DMSO}-d_{6}\right)$ as internal standard, and coupling constants $(J)$ are reported in Hertz $(\mathrm{Hz})$. The multiplicities are abbreviated as follows: $\mathrm{s}=$ singlet, $\mathrm{d}=$ doublet, $\mathrm{t}=$ triplet, $\mathrm{q}=$ quartet, quint $=$ quintet, sext $=$ sextet, sept $=$ septet, $\mathrm{m}=$ multiplet, $\mathrm{br}=$ broad signal. High-resolution mass spectra were obtained on a Thermo Finigan MAT95XP, magnetic sector mass spectrometer, electron ionization. HPLC method 1: Performed on a Shimadzu UFLCXR system coupled to an Applied Biosystems API2000; column maintained at $40{ }^{\circ} \mathrm{C}$; column, Phenomenex Gemini-NX $3 \mu \mathrm{m}, 110 \AA \mathrm{C} 18,50 \mathrm{~mm} \times 2 \mathrm{~mm}$; total flow rate 0.5 $\mathrm{mL} / \mathrm{min}$; UV detection at $220 \mathrm{~nm}$ (channel 2) and $254 \mathrm{~nm}$ (channel 1); gradient, pre-equilibration run for one min at $5 \% \mathrm{~B}$, then method run $5-98 \%$ solvent B in $2 \mathrm{~min}, 98 \%$ B for $2 \mathrm{~min}, 98-5 \% \mathrm{~B}$ in $0.5 \mathrm{~min}$ then $5 \%$ for $1 \mathrm{~min}$; acid method solvent $A=0.1 \%$ formic acid in water and solvent $\mathrm{B}=0.1 \%$ formic acid in MeCN. HPLC method 2: Performed on an Agilent HPLC; column, Waters X-Select C18 $2.5 \mu \mathrm{m}, 4.6 \mathrm{~mm} \times 30$ $\mathrm{mm}$, using standard acidic (0.1\% formic acid) 4 min method, 5-95\% $\mathrm{MeCN} /$ water, UV detection at $254 \mathrm{~nm}$. HPLC method 3: Performed on a Waters ACQUITY UPLC with PDA detector scanning between 210 and $400 \mathrm{~nm}$. Mass spectral data was obtained using a Waters ACQUITY QDa detector scanning in the positive $\left(\mathrm{ES}^{+}\right)$and negative $\left(\mathrm{ES}^{-}\right)$modes between $\mathrm{m} / z$ 100-650. Samples were passed through a

\section{Table 4. Effects of Introducing 2,6-Di-isopropylpyridine on Potency and Selectivity of Compound $19^{a}$}

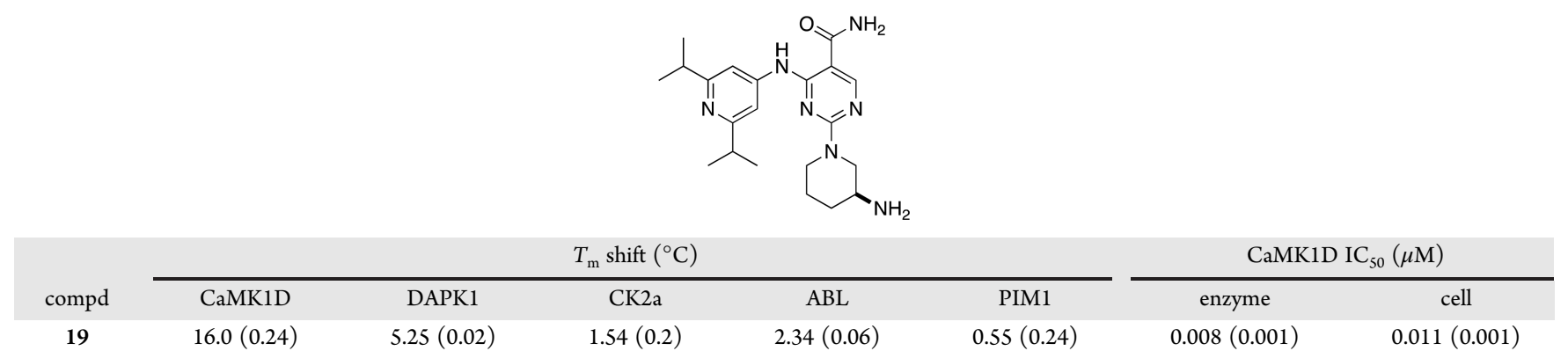

${ }^{a}$ All data represent mean of at least $n=3$ independent experiments with standard deviation in parentheses. 


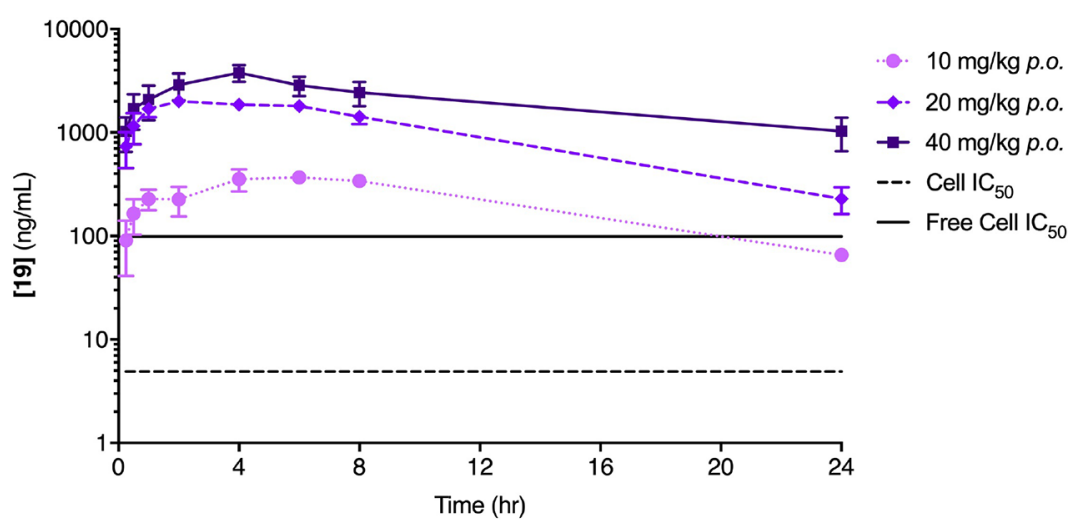

\begin{tabular}{ccccccc} 
& Mouse & \multicolumn{5}{c}{ Rat } \\
\hline Route & i.v. & p.o. & p.o. & p.o. & i.v. & p.o. \\
Dose $(\mathrm{mg} / \mathrm{kg})$ & 2 & 10 & 20 & 40 & 2 & 10 \\
\hline $\mathrm{F} \%$ & - & 44 & 118 & 100 & - & 67.5 \\
$\mathrm{CL}(\mathrm{mL} / \mathrm{min} / \mathrm{kg})$ & 13.7 & - & - & - & 36.5 & - \\
$\mathrm{AUC}(0-\mathrm{inf}, \mathrm{ng} \cdot \mathrm{hr} / \mathrm{mL})$ & 2454 & 5408 & 28923 & 49220 & 913 & 3058 \\
$\mathrm{C}_{\max }(\mathrm{ng} / \mathrm{mL})$ & 503 & 387 & 2015 & 3792 & 391 & 199 \\
$\mathrm{t}_{1 / 2}(\mathrm{~h})$ & 8.3 & 5.9 & 5.9 & 6.2 & 7.7 & 7.0 \\
$\mathrm{~V}_{\mathrm{ss}}$ & 7.46 & - & - & - & 18.5 & - \\
$\mathrm{Kp}, \mathrm{uu}\left(@ \mathrm{t}_{\max }\right)$ & - & - & - & - & - & 0.001
\end{tabular}

Figure 7. In vivo pharmacokinetic profile of 19 in male CD-1 mice $(25-40 \mathrm{~g})$ and male Crl:CD Sprague-Dawley rats (250-400 g) dosed in $10 \%$ $\mathrm{DMSO} / 90 \%$ hydroxypropyl- $\beta$-cyclodextrin $(20 \% \mathrm{w} / \mathrm{v}), n=3$ per group. Free cell $\mathrm{IC}_{50}$ calculated by dividing measured cellular $\mathrm{IC}_{50}$ by free fraction in mouse plasma.
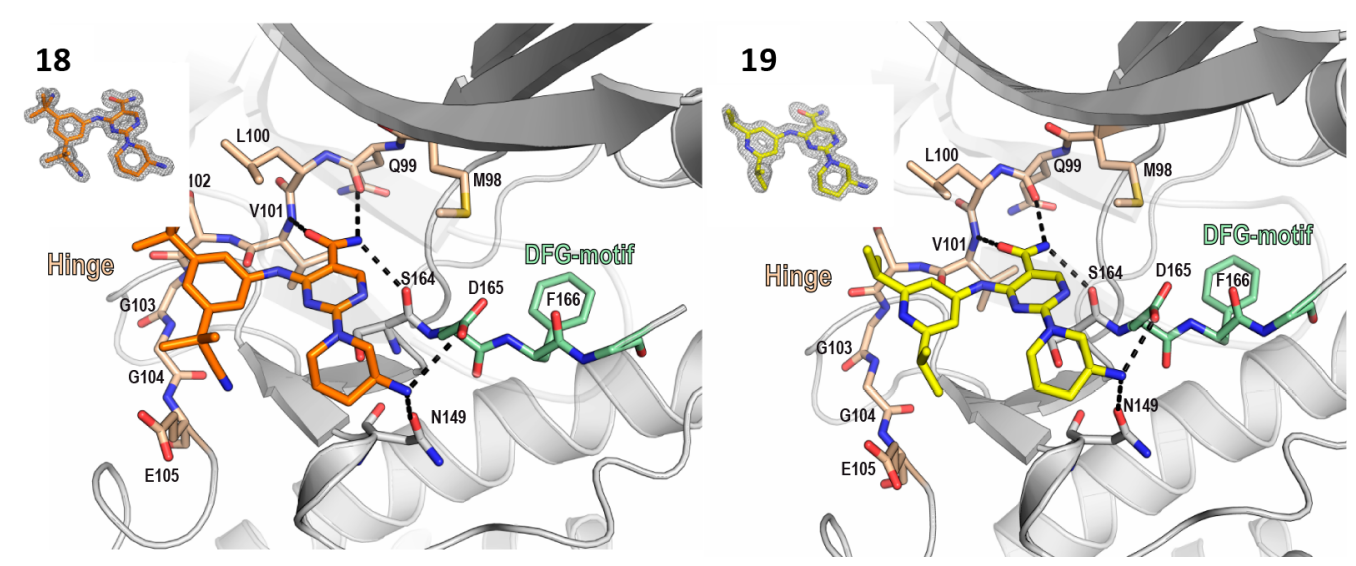

Figure 8. Comparison of the CaMK1D bound structures of compounds 18 (6T29) and 19 (6T28). CaMK1D is shown as gray cartoon representation, the hinge region is highlighted in wheat, and the DFG motif is shown in green color. Important residues and inhibitors are shown in stick representation. For better visibility, the P-Loop has been made transparent. Hydrogen bonds are indicated as black dashed lines. The insets on the upper left of each figure show the electron density of the compounds as $2 F_{\mathrm{o}}-F_{\mathrm{c}}$ maps contoured at $1.5 \sigma$.

Waters ACQUITY UPLC BEH C18 $1.7 \mu \mathrm{m}, 2.1 \mathrm{~mm} \times 50 \mathrm{~mm}$ column coupled to a Waters ACQUITY UPLC BEH C18 VanGuard precolumn $2.1 \mathrm{~mm} \times 5 \mathrm{~mm}$. Gradient: Pre-equilibration run for $30 \mathrm{~s}$ at $5 \% \mathrm{~B}$; then method run $5-95 \%$ solvent B in 2 min, $95 \%$ B for $30 \mathrm{~s}, 95-5 \%$ B in $6 \mathrm{~s}$, then $5 \% \mathrm{~B}$ for $54 \mathrm{~s}$. The column was maintained at $40{ }^{\circ} \mathrm{C}$. Acid method: solvent $\mathrm{A}=0.1 \%$ formic acid in water; solvent $\mathrm{B}=\mathrm{MeCN}$. Base method: solvent $\mathrm{A}=0.1 \%$ ammonium hydroxide in water; solvent $\mathrm{B}=\mathrm{MeCN}$. HPLC method 4: Performed on an Agilent HPLC; column Waters XBridge C18 $2.5 \mu \mathrm{m}, 4.6 \mathrm{~mm} \times 30 \mathrm{~mm}$, using standard basic $(0.1 \%$ ammonium bicarbonate) 4 min method, 5-95\% MeCN/water, UV detection at $254 \mathrm{~nm}$. Compound purity was assessed by HPLC method 1 using both Phenomenex Gemini-NX $3 \mu \mathrm{m}, 110 \AA \AA \mathrm{C} 18,50 \mathrm{~mm} \times 2$ $\mathrm{mm}$ and Phenomenex Luna-NX $3 \mu \mathrm{m}, 110 \AA ̊$ PFP, $50 \mathrm{~mm} \times 2 \mathrm{~mm}$ columns, with UV detection at $254 \mathrm{~nm}$. All compounds demonstrate purity $>95 \%$ by both methods, with the exception of $\mathbf{5}$, which demonstrates $92.5 \%$ purity on the Gemini C-18 column and $96.4 \%$ purity on the Luna PFP column. 
Table 5. In Vitro Pharmacokinetic and Toxicology Profile of 18 and 19

\begin{tabular}{lll} 
& \multicolumn{1}{c}{$\mathbf{1 8}$} & \multicolumn{1}{c}{19} \\
LogD & 2.3 & 2.6 \\
solubility $(\mu \mathrm{M})$ & 52 & $>200$ \\
mouse/rat/human MICs $\left(\mu \mathrm{L} \cdot \mathrm{min}^{-1} \cdot \mathrm{mg}^{-1}\right)$ & $15 /<1 / 13$ & $6 / 3 / 7$ \\
mouse/rat/human Heps $\left(\mu \mathrm{L} \cdot \mathrm{min}^{-1}\right.$ per $10^{6}$ cells $)$ & $13 / 11 / b$ & $14 / b / 19$ \\
mouse/rat/human PPB $(\%$ bound $)$ & $98.4 / 94 / b$ & $94 / 92 / 89$ \\
CaCo2 $P_{\text {app }}\left(\mathrm{A}-\mathrm{B} \times 10^{-6} \mathrm{~cm} / \mathrm{s}\right) /$ efflux ratio & $1.1 / 13.4$ & $0.4 / 7.9$ \\
CYP450 2C9/2C19 IC $50(\mu \mathrm{M})^{a}$ & $6 / 1$ & $6 / 10$ \\
Ionworks hERG $\mathrm{IC}_{50}(\mu \mathrm{M}) / \mathrm{ratio}$ to cell $\mathrm{IC}_{50}$ & $7.1 / 284$ & $3.7 / 336$
\end{tabular}

${ }^{a} \mathrm{CYP} 4501 \mathrm{~A} 2,2 \mathrm{D} 6$, and $3 \mathrm{~A} 45 \mathrm{IC}_{50}>20 \mu \mathrm{M}$ for all compounds. ${ }^{b} \mathrm{Not}$ determined.

2-((2-Aminoethyl)amino)-4-((3-(trifluoromethyl)phenyl)amino)pyrimidine-5-carboxamide hydrochloride (1). Compound prepared following a reported method. ${ }^{16}{ }^{1} \mathrm{H} \mathrm{NMR}(400 \mathrm{MHz}$, DMSO-d 6 ) $\delta 12.34(\mathrm{~s}, 1 \mathrm{H}), 8.91(\mathrm{~s}, 1 \mathrm{H}), 8.61(\mathrm{br} \mathrm{s}, 2 \mathrm{H}), 8.32(\mathrm{br} \mathrm{s}$, $3 \mathrm{H}), 8.13(\mathrm{~s}, 1 \mathrm{H}), 7.90(\mathrm{~d}, J=8.1 \mathrm{~Hz}, 1 \mathrm{H}), 7.70$ (app. $\mathrm{t}, J=8.1 \mathrm{~Hz}, 1 \mathrm{H})$, $7.55(\mathrm{~d}, J=8.1 \mathrm{~Hz}, 1 \mathrm{H}), 3.64$ (app. q, $J=5.6 \mathrm{~Hz}, 2 \mathrm{H}), 3.01$ (app. q, $J=$ $5.6 \mathrm{~Hz}, 2 \mathrm{H})$; LC-MS $m / z\left(\mathrm{ES}^{+}\right)(\mathrm{M}+\mathrm{H})^{+} 341.2 ; t_{\mathrm{R}}=1.98 \mathrm{~min}$. HPLC method 1. HRMS (ES-TOF): $m / z$ calcd for $\mathrm{C}_{14} \mathrm{H}_{16} \mathrm{~F}_{3} \mathrm{~N}_{6} \mathrm{O} 341.1332$, found $341.1346[\mathrm{M}+\mathrm{H}]^{+}$.

2-((2-Aminoethyl)amino)- $\mathrm{N}$-methyl-4-((3-(trifluoromethyl)phenyl)amino)pyrimidine-5-carboxamide (2). Compound prepared following a reported method. ${ }^{16}{ }^{1} \mathrm{H}$ NMR (DMSO- $\left.d_{6}\right) \delta 12.21(\mathrm{~s}$, $1 \mathrm{H}), 9.30(\mathrm{~d}, J=3.9 \mathrm{~Hz}, 1 \mathrm{H}), 8.88(\mathrm{~s}, 1 \mathrm{H}), 8.66($ app.t, $J=5.2 \mathrm{~Hz}, 1 \mathrm{H})$, $8.26(\mathrm{br} \mathrm{s}, 3 \mathrm{H}), 8.14(\mathrm{~s}, 1 \mathrm{H}), 7.91(\mathrm{~d}, J=7.9 \mathrm{~Hz}, 1 \mathrm{H}), 7.70$ (app. $\mathrm{t}, J=$ $7.9 \mathrm{~Hz}, 1 \mathrm{H}), 7.56(\mathrm{~d}, J=7.8 \mathrm{~Hz}, 1 \mathrm{H}), 3.64$ (app. q, $J=4.8 \mathrm{~Hz}, 2 \mathrm{H}), 3.02$ (app. q, $J=4.8 \mathrm{~Hz}, 2 \mathrm{H}), 2.78(\mathrm{~d}, J=4.4 \mathrm{~Hz}, 3 \mathrm{H})$; LC-MS $m / z\left(\mathrm{ES}^{+}\right)(\mathrm{M}$
$+\mathrm{H})^{+}$355.2; $t_{\mathrm{R}}=1.99$ min. HPLC method 1. HRMS (ES-TOF): $\mathrm{m} / z$ calcd for $\mathrm{C}_{15} \mathrm{H}_{17} \mathrm{~F}_{3} \mathrm{~N}_{6} \mathrm{ONa}$ 377.1308, found 377.1301 [M $\left.+\mathrm{Na}\right]^{+}$.

2-((2-Aminoethyl)(methyl)amino)-4-((3-(trifluoromethyl)phenyl)amino)pyrimidine-5-carboxamide Hydrochloride (3). To a suspension of 2-((1H-benzo[d][1,2,3]triazol-1-yl)oxy)-4-((3(trifluoromethyl)phenyl)amino)pyrimidine-5-carboxamide 21 (0.11 g, $0.25 \mathrm{mmol})$, prepared following a reported method, ${ }^{16}$ in THF $(2 \mathrm{~mL})$ and DMF $(1 \mathrm{~mL})$ was added $N$-boc-2-methylamino-ethylamine $(50$ $\mathrm{mg}, 0.28 \mathrm{mmol}$ ), and the mixture was stirred for $30 \mathrm{~min}$ at room temperature. The mixture was diluted with water and extracted with AcOEt. The organic layer was dried over anhydrous $\mathrm{Na}_{2} \mathrm{SO}_{4}$ and concentrated under reduced pressure. $m / z\left(\mathrm{ES}^{+}\right)(\mathrm{M}+\mathrm{H})^{+} 455.0 ; t_{\mathrm{R}}=$ $2.74 \mathrm{~min}$. HPLC method 1 . The crude was dissolved in $\mathrm{CH}_{2} \mathrm{Cl}_{2}(2 \mathrm{~mL})$, and $4 \mathrm{~N} \mathrm{HCl}$ in dioxane $(5 \mathrm{~mL})$ was added. The suspension was stirred at RT for $1 \mathrm{~h}$ (completion monitored by HPLC). The suspension was concentrated, and $\mathrm{Et}_{2} \mathrm{O}$ was added to induce precipitation. The resulting white solid was centrifuged, washed again with $\mathrm{Et}_{2} \mathrm{O}$, and dried under vacuum affording the titled compound $(50 \mathrm{mg}, 81 \%) .{ }^{1} \mathrm{H}$ NMR $\left(400 \mathrm{MHz}, \mathrm{MeOD}-d_{4}\right) \delta 8.61(\mathrm{~s}, 1 \mathrm{H}), 8.09(\mathrm{br} \mathrm{s}, 1 \mathrm{H}), 7.78(\mathrm{~d}, J=7.6$ $\mathrm{Hz}, 1 \mathrm{H}), 7.66$ (app. t, $J=7.8 \mathrm{~Hz}, 1 \mathrm{H}), 7.57(\mathrm{~d}, J=7.6 \mathrm{~Hz}, 1 \mathrm{H}), 3.99(\mathrm{t}, J$ $=5.7 \mathrm{~Hz}, 2 \mathrm{H}), 3.36(\mathrm{~s}, 3 \mathrm{H}), 3.26(\mathrm{br} \mathrm{s}, 2 \mathrm{H})$; LC-MS $m / z\left(\mathrm{ES}^{+}\right)(\mathrm{M}+$ $\mathrm{H})^{+} 355.2 ; t_{\mathrm{R}}=2.09$ min. HPLC method 1. HRMS (ES-TOF): $\mathrm{m} / z$ calcd for $\mathrm{C}_{15} \mathrm{H}_{18} \mathrm{~F}_{3} \mathrm{~N}_{6} \mathrm{O} 355.1489$, found $355.1503[\mathrm{M}+\mathrm{H}]^{+}$.

2-(Methyl (2-(methylamino)ethyl)amino) - 4- ( (3(trifluoromethyl)phenyl)amino)pyrimidine-5-carboxamide Hydrochloride (4). Prepared in analogous manner to 3 using $N$-boc2,4-dimethylamino-ethylamine. ${ }^{1} \mathrm{H}$ NMR $\left(400 \mathrm{MHz}, \mathrm{MeOD}-d_{4}\right) \delta 8.62$ $(\mathrm{s}, 1 \mathrm{H}), 8.06(\mathrm{br} \mathrm{s}, 1 \mathrm{H}), 7.82(\mathrm{~d}, J=7.8 \mathrm{~Hz}, 1 \mathrm{H}), 7.69$ (app. t, $J=7.8 \mathrm{~Hz}$, $1 \mathrm{H}), 7.60(\mathrm{brd}, J=7.1 \mathrm{~Hz}, 1 \mathrm{H}), 4.05(\mathrm{t}, J=5.6 \mathrm{~Hz}, 2 \mathrm{H}), 3.38(\mathrm{~s}, 3 \mathrm{H})$, 3.32 (br s, $2 \mathrm{H}), 2.59$ (br s, 3H); LC-MS $m / z\left(\mathrm{ES}^{+}\right)(\mathrm{M}+\mathrm{H})^{+} 369.2 ; t_{\mathrm{R}}$ $=2.12$ min. HPLC method 1. HRMS (ES-TOF): $\mathrm{m} / z$ calcd for $\mathrm{C}_{16} \mathrm{H}_{20} \mathrm{~F}_{3} \mathrm{~N}_{6} \mathrm{O} 369.1645$, found $369.1659[\mathrm{M}+\mathrm{H}]^{+}$.

2-((2-(Dimethylamino)ethyl) (methyl)amino)-4-((3(trifluoromethyl)phenyl)amino)pyrimidine-5-carboxamide

\section{A}
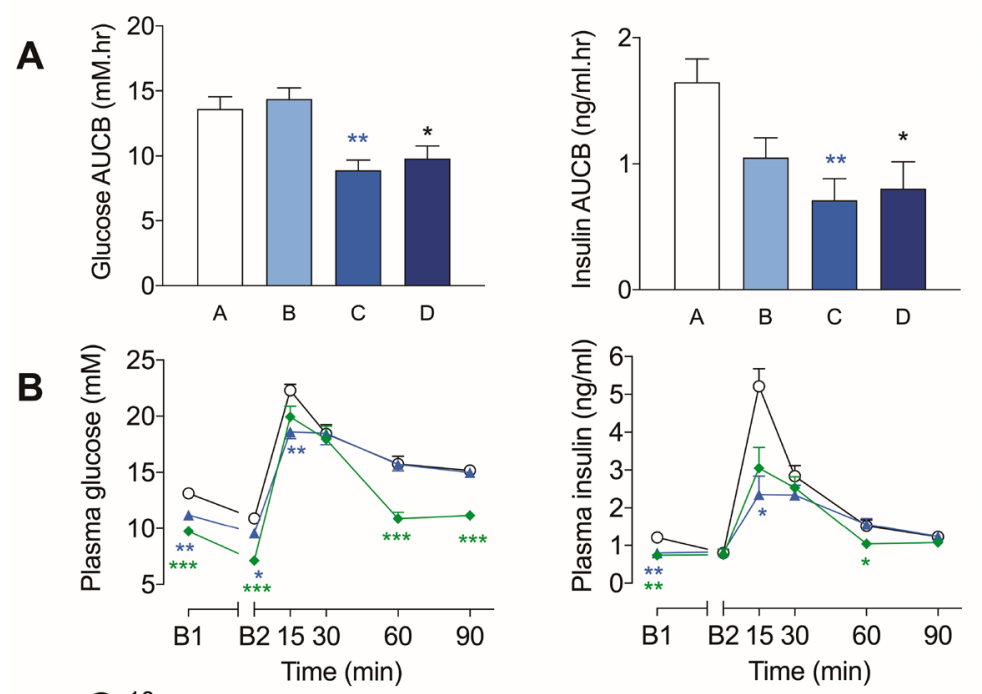

-o- A: Vehicle po bid

$\square$ (14 days)

\ B: $1825 \mathrm{mg} / \mathrm{kg}$ po bid

$\square$ (14 days)

$\rightarrow$ C: Liraglutide $0.1 \mathrm{mg} / \mathrm{kg} \mathrm{sc}$

$\square$ (14 days)
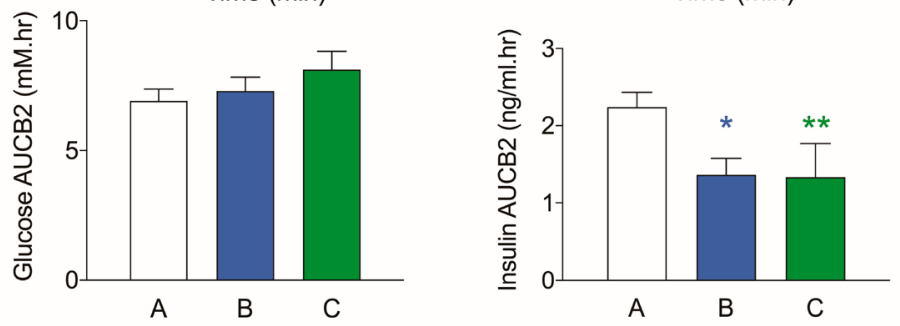

Figure 9. In vivo activity of compound 18 following oral glucose tolerance test (OGTT) in diet induced obesity mouse model (male C57Bl/6J mice) following (A) single dose $4 \mathrm{~h}$ prior to OGTT ( $n=6$ per group) and (B) 14 day repeat dosing ( $n=8$ per group). Significant differences (from vehicle), determined by multiple $t$ test comparisons, are denoted by $* p<0.05, * * p<0.01$, and $* * * p<0.001$. 
Scheme 1. Synthetic Route to Compounds 3-8 ${ }^{a}$

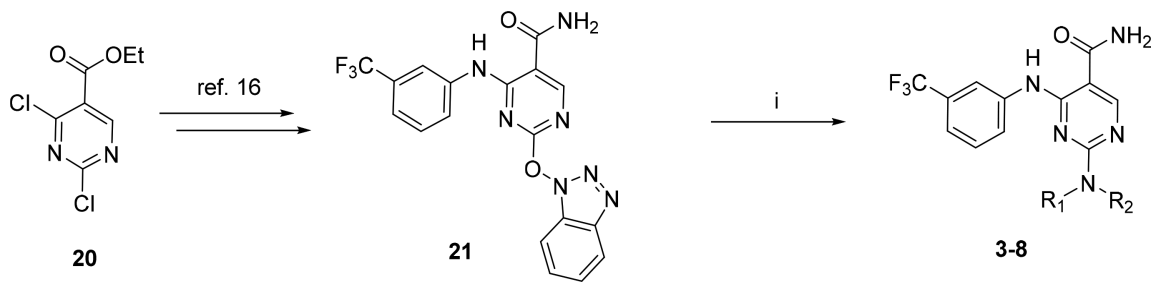

${ }^{a}$ Reagents and conditions: (i) N-Boc-diamine, THF/DMF, RT, $30 \mathrm{~min}$; then DCM, $4 \mathrm{~N} \mathrm{HCl}$ in dioxane, RT, $1 \mathrm{~h}, 81 \%$.

Scheme 2. General Synthetic Route to Compounds 9-19 ${ }^{a}$<smiles>NC(=O)c1cnc(Cl)nc1Cl</smiles>

22<smiles>[R3]c1cc([R3])cc(Nc2nc(Cl)ncc2C(N)=O)c1</smiles>

$\mathrm{R}^{\prime} \quad \mathrm{Cl}$<smiles>[R3]c1cc([R3])cc(Nc2nc(N3CCC[C@@H](NC(C)(C)C)C3)ncc2C(N)=O)c1</smiles><smiles>[R3]c1cc(Br)cc(Nc2nc(N3CCC[C@@H](N)C3)ncc2C(N)=O)c1</smiles>

$9-19$

${ }^{a}$ Reagents and conditions: (i) aniline, $\mathrm{iPr}_{2} \mathrm{NEt}, \mathrm{MeCN}$ or dioxane, reflux, $16 \mathrm{~h}$; (ii) (S)-tert-butyl piperidin-3-ylcarbamate, DIPEA, solvent, RT, 2$16 \mathrm{~h}$; (iii) TFA/DCM or $4 \mathrm{~N} \mathrm{HCl}$ in dioxane, RT, $1 \mathrm{~h}, 10-73 \%$ over 3 steps.

Scheme 3. Synthesis of Di-alkyl (Hetero)anilines 27 and 28, Used in Compounds 15 and $19^{a}$

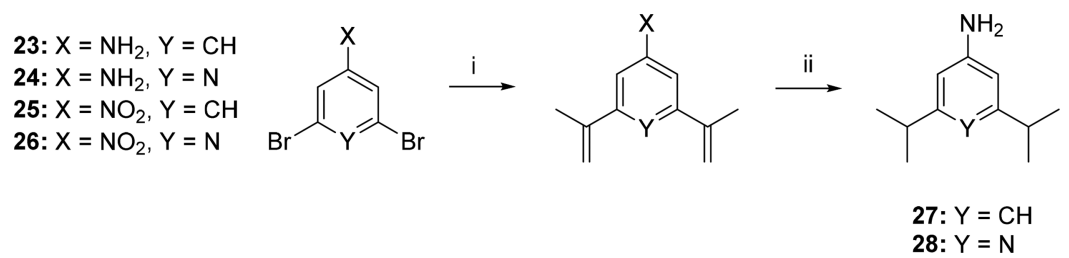

${ }^{a}$ Reagents and conditions: (i) (4,4,5,5-tetramethyl-1,3,2-dioxaborolan-2-yl)isoprene, $\mathrm{NaHCO}_{3}, \mathrm{Pd}(\mathrm{dppf}) \mathrm{Cl}_{2}$ or $\mathrm{Pd}\left(\mathrm{PPh}_{3}\right)_{4}, 1,4-$ dioxane, water, 90 ${ }^{\circ} \mathrm{C}, 4-16$ h, 54-83\%; (ii) $\mathrm{H}_{2}, \mathrm{Pd} / \mathrm{C}, \mathrm{MeOH}, \mathrm{RT}, 2-16$ h, 75-98\%.

Scheme 4. Synthesis of Aniline 34, Used in Compound $16^{a}$

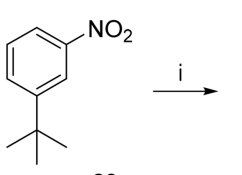

29<smiles>CC(C)C(C)(C)c1cc([N+](=O)[O-])cc(S(=O)(=O)Cl)c1</smiles>

30<smiles>CC(C)(C)c1cc(S)cc([N+](=O)[O-])c1</smiles>

31<smiles>CSc1cc([N+](=O)[O-])cc(C(C)(C)C)c1</smiles>

32<smiles>[3H]C#N</smiles><smiles>CC#CC</smiles><smiles>CC(C)(C)c1cc([N+](=O)[O-])cc(S(C)(=O)=O)c1</smiles>

${ }^{a}$ Reagents and conditions: (i) chlorosulfonic acid, $\mathrm{CHCl}_{3}$, reflux, 48 h, 85\%; (ii) $\mathrm{P}(\mathrm{Ph}$ ) , toluene, RT, 10 min, $72 \%$; (iii) $\mathrm{NaOH}, \mathrm{MeI}, \mathrm{EtOH}, \mathrm{RT}$, 16 h, 98\%; (iv) m-CPBA, DCM, $0{ }^{\circ} \mathrm{C}$ to RT, 2 h, 73\%; (v) $\mathrm{H}_{2}$ (5 atm), $\mathrm{Pd} / \mathrm{C}, \mathrm{MeOH}, 16 \mathrm{~h}, 76 \%$.

Hydrochloride (5). Prepared in analogous manner to 3 with $\mathrm{N}$-boc2,4,4-trimethylamino-ethylamine. ${ }^{1} \mathrm{H}$ NMR $\left(400 \mathrm{MHz}, \mathrm{MeOD}-d_{4}\right) \delta$ $8.61(\mathrm{~s}, 1 \mathrm{H}), 7.96($ br s, $1 \mathrm{H}), 7.82(\mathrm{~d}, J=7.1 \mathrm{~Hz}, 1 \mathrm{H}), 7.70$ (app. t, $J=$ $7.4 \mathrm{~Hz}, 1 \mathrm{H}), 7.63$ (br s, $1 \mathrm{H}), 4.09$ (app. t, $J=5.4 \mathrm{~Hz}, 2 \mathrm{H}), 3.42$ (br s, $2 \mathrm{H}), 3.33(\mathrm{~s}, 3 \mathrm{H}), 2.68(\mathrm{br} \mathrm{s}, 6 \mathrm{H})$; LC-MS $m / z\left(\mathrm{ES}^{+}\right)(\mathrm{M}+\mathrm{H})^{+}$383.2; $t_{\mathrm{R}}=2.12 \mathrm{~min}$. HPLC method 1. HRMS (ES-TOF): $\mathrm{m} / z$ calcd for $\mathrm{C}_{17} \mathrm{H}_{22} \mathrm{~F}_{3} \mathrm{~N}_{6} \mathrm{O} 383.1802$, found $383.1824[\mathrm{M}+\mathrm{H}]^{+}$.

(rac)-2-(3-Aminopiperidin-1-yl)-4-((3-(trifluoromethyl)phenyl)amino)pyrimidine-5-carboxamide Hydrochloride (6).
Prepared in analogous manner to 3 using $( \pm)$ tert-butyl-piperidin-3ylcarbamate. ${ }^{1} \mathrm{H}$ NMR $\left(400 \mathrm{MHz}, \mathrm{MeOD}-d_{4}\right) \delta 8.60(\mathrm{~s}, 1 \mathrm{H}), 8.10$ (br s, $1 \mathrm{H}), 7.81(\mathrm{brd} J=7.1 \mathrm{~Hz}, 1 \mathrm{H}), 7.67(\mathrm{t}, J=7.8 \mathrm{~Hz}, 1 \mathrm{H}), 7.56(\mathrm{~d}, J=7.8$ $\mathrm{Hz}, 1 \mathrm{H}), 4.35$ (dd, $J=13.5,3.7 \mathrm{~Hz}, 1 \mathrm{H}), 4.06(\mathrm{br} \mathrm{s}, 1 \mathrm{H}), 3.73$ (dd, $J=$ $13.5,8.4 \mathrm{~Hz}, 1 \mathrm{H}), 3.64-3.57(\mathrm{~m}, 1 \mathrm{H}), 3.54-3.48(\mathrm{~m}, 1 \mathrm{H}), 2.24-2.16$ (m, 1H), 2.02-1.94 (m, 1H), 1.88-1.75 (m, 2H); LC-MS m/z $\left(\mathrm{ES}^{+}\right)$ $(\mathrm{M}+\mathrm{H})^{+} 381.4 ; t_{\mathrm{R}}=2.14 \mathrm{~min}$. HPLC method 1. HRMS (ES-TOF): $m / z$ calcd for $\mathrm{C}_{17} \mathrm{H}_{20} \mathrm{~F}_{3} \mathrm{~N}_{6} \mathrm{O}$ 381.1645, found 381.1662 [M+ H] $]^{+}$. 
Scheme 5. Synthesis of 2-Cyanoisopropyl Substituted Anilines Used in Compounds 17 and $18^{a}$

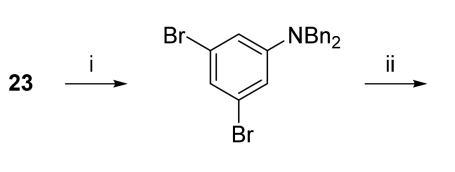

35<smiles>CC(C)(C)c1cc(NC(=O)c2ccccc2)cc(C(C)(C)C#N)c1</smiles>

36<smiles>CC(C)(C)c1cc(N)cc(C(C)(C)C#N)c1</smiles><smiles>CCCCCCCCCCCCCC(C)(C)C#N</smiles>

37<smiles>CCCCNc1cc(-c2ccccc2)cc(C(C)(C)C#N)c1</smiles>

39

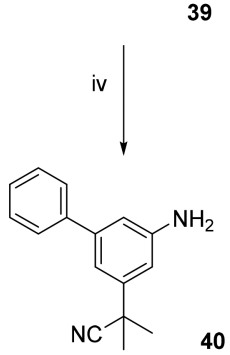

${ }^{a}$ Reagents and conditions: (i) Benzyl bromide, $\mathrm{K}_{2} \mathrm{CO}_{3}, \mathrm{MeCN}$, reflux, $24 \mathrm{~h}, 73 \%$; (ii) potassium 2-cyano-2-methylpropanoate, mesitylene, Xantphos, $\mathrm{Pd}_{2}(\text { allyl })_{2} \mathrm{Cl}_{2}, 140{ }^{\circ} \mathrm{C}, 24 \mathrm{~h}, 36=53 \%, 37=20 \%$; (iii) 4,4,5,5-tetramethyl-2-phenyl-1,3,2-dioxaborolane, $\mathrm{Pd}\left(\mathrm{PPh}_{3}\right)_{2} \mathrm{Cl}_{2}, \mathrm{~K}_{2} \mathrm{CO}_{3}$, dioxane:water, $100{ }^{\circ} \mathrm{C}, 1 \mathrm{~h}, 74 \%$; (iv) $\mathrm{H}_{2}$, Pd/C, MeOH:DCM, 18 h, 88-98\%.

(R)-2-(3-Aminopiperidin-1-yl)-4-((3-(trifluoromethyl)phenyl)amino)pyrimidine-5-carboxamide Hydrochloride (7). Prepared in analogous manner to 3 using tert-butyl $(R)$-piperidin-3ylcarbamate. ${ }^{1} \mathrm{H}$ NMR $\left(400 \mathrm{MHz}, \mathrm{MeOD}-d_{4}\right) \delta 8.60(\mathrm{~s}, 1 \mathrm{H}), 8.10$ (br s, $1 \mathrm{H}), 7.81(\mathrm{brd}, J=7.1 \mathrm{~Hz}, 1 \mathrm{H}), 7.67(\mathrm{t}, J=7.8 \mathrm{~Hz}, 1 \mathrm{H}), 7.56(\mathrm{~d}, J=7.8$ $\mathrm{Hz}, 1 \mathrm{H}), 4.35(\mathrm{dd}, J=13.5,3.7 \mathrm{~Hz}, 1 \mathrm{H}), 4.06(\mathrm{br} \mathrm{s}, 1 \mathrm{H}), 3.73(\mathrm{dd}, J=$ $13.5,8.4 \mathrm{~Hz}, 1 \mathrm{H}), 3.64-3.57(\mathrm{~m}, 1 \mathrm{H}), 3.54-3.48(\mathrm{~m}, 1 \mathrm{H}), 2.24-2.16$ (m, 1H), 2.02-1.94 (m, 1H), 1.88-1.75 (m, 2H); LC-MS m/z $\left(\mathrm{ES}^{+}\right)$ $(\mathrm{M}+\mathrm{H})^{+} 381.4 ; t_{\mathrm{R}}=2.14 \mathrm{~min}$. HPLC method 1. HRMS (ES-TOF): $m / z$ calcd for $\mathrm{C}_{17} \mathrm{H}_{20} \mathrm{~F}_{3} \mathrm{~N}_{6} \mathrm{O} 381.1645$, found $381.1655[\mathrm{M}+\mathrm{H}]^{+}$.

(S)-2-(3-Aminopiperidin-1-yl)-4-((3-(trifluoromethyl)phenyl)amino)pyrimidine-5-carboxamide Hydrochloride (8). Prepared in analogous manner to 3 using tert-butyl $(S)$-piperidin-3ylcarbamate. ${ }^{1} \mathrm{H}$ NMR $\left(400 \mathrm{MHz}, \mathrm{MeOD}-d_{4}\right) \delta 8.60(\mathrm{~s}, 1 \mathrm{H}), 8.10$ (br s, $1 \mathrm{H}), 7.81(\mathrm{brd}, J=7.1 \mathrm{~Hz}, 1 \mathrm{H}), 7.67(\mathrm{t}, J=7.8 \mathrm{~Hz}, 1 \mathrm{H}), 7.56(\mathrm{~d}, J=7.8$ $\mathrm{Hz}, 1 \mathrm{H}), 4.35$ (dd, $J=13.5,3.7 \mathrm{~Hz}, 1 \mathrm{H}), 4.06(\mathrm{br} \mathrm{s}, 1 \mathrm{H}), 3.73$ (dd, $J=$ $13.5,8.4 \mathrm{~Hz}, 1 \mathrm{H}), 3.64-3.57(\mathrm{~m}, 1 \mathrm{H}), 3.54-3.48(\mathrm{~m}, 1 \mathrm{H}), 2.24-2.16$ $(\mathrm{m}, 1 \mathrm{H}), 2.02-1.94(\mathrm{~m}, 1 \mathrm{H}), 1.88-1.75(\mathrm{~m}, 2 \mathrm{H})$; LC-MS $m / z\left(\mathrm{ES}^{+}\right)$ $(\mathrm{M}+\mathrm{H})^{+} 381.0 ; t_{\mathrm{R}}=2.15 \mathrm{~min}$. HPLC method 1. HRMS (ES-TOF): $\mathrm{m} / z$ calcd for $\mathrm{C}_{17} \mathrm{H}_{20} \mathrm{~F}_{3} \mathrm{~N}_{6} \mathrm{O} 381.1645$, found $381.1655[\mathrm{M}+\mathrm{H}]^{+}$.

(S)-2-(3-Aminopiperidin-1-yl)-4-((4-(trifluoromethyl)phenyl)amino)pyrimidine-5-carboxamide Hydrochloride (9). 3,5-Bis(trifluoromethyl)aniline $(85 \mathrm{mg}, 0.37 \mathrm{mmol}$ ) was added to a solution of 2,4-dichloropyrimidine-5-carboxamide $22(75 \mathrm{mg}, 0.39$ mmol) and DIPEA $(0.17 \mathrm{~mL}, 0.98 \mathrm{mmol})$ in dioxane $(5 \mathrm{~mL})$ and stirred at $80^{\circ} \mathrm{C}$ for $16 \mathrm{~h}$. The reaction was concentrated under reduced pressure $(38 \mathrm{mg}, 20 \%)$. LC-MS $m / z\left(\mathrm{ES}^{+}\right)(\mathrm{M}+\mathrm{H})^{+} 385.0 ; t_{\mathrm{R}}=2.44$ min. HPLC method 2.

(S)-tert-Butyl piperidin-3-ylcarbamate $(62 \mathrm{mg}, 0.23 \mathrm{mmol})$ was added to a solution of 4-((3,5-bis(trifluoromethyl)phenyl)amino)-2chloropyrimidine-5-carboxamide $(38 \mathrm{mg}, 0.10 \mathrm{mmol})$ and TEA $(69 \mu \mathrm{L}$, $0.49 \mathrm{mmol})$ in dioxane $(10 \mathrm{~mL})$. The reaction was stirred at RT for 16 h. The mixture was diluted with $\mathrm{Et}_{2} \mathrm{O}(10 \mathrm{~mL})$, filtered, and washed with $\mathrm{CH}_{2} \mathrm{Cl}_{2} / \mathrm{MeOH} / \mathrm{Et}_{2} \mathrm{O}$ (9:1:9 mL). No further purification was required $(20 \mathrm{mg}, 19 \%$ yield $)$. LC-MS $m / z\left(\mathrm{ES}^{+}\right)(\mathrm{M}+\mathrm{H})^{+} 549.0 ; t_{\mathrm{R}}=$ 2.75 min. HPLC method 2.

(S)-tert-Butyl (1-(4-((3,5-bis(trifluoromethyl)phenyl)amino)-5carbamoylpyrimidin-2-yl)piperidin-3-yl)carbamate $(20 \mathrm{mg}, 0.04$ mmol) was treated with TFA $(0.10 \mathrm{~mL}, 1.08 \mathrm{mmol})$ in $\mathrm{CH}_{2} \mathrm{Cl}_{2}(1$ $\mathrm{mL}$ ). The reactions were stirred for $2 \mathrm{~h}$ and concentrated under reduced pressure. The residues were diluted in $\mathrm{MeOH}(0.20 \mathrm{~mL})$ and loaded onto a SCX cartridge, washing with $\mathrm{MeOH}$ (3 column volumes) and eluting with $1 \% \mathrm{NH}_{3} \mathrm{MeOH}$ (3 column volumes). The ammonical $\mathrm{MeOH}$ was removed under reduced pressure to give the product $(12$ $\mathrm{mg}, 16 \%$ yield over 3 steps). ${ }^{1} \mathrm{H}$ NMR $\left(400 \mathrm{MHz}, \mathrm{MeOD}-d_{4}\right) \delta 8.63$ (s, $1 \mathrm{H}), 8.41-8.31(\mathrm{~m}, 2 \mathrm{H}), 7.60(\mathrm{~s}, 1 \mathrm{H}), 4.67-4.60(\mathrm{~m}, 1 \mathrm{H}), 4.50-4.43$ $(\mathrm{m}, 1 \mathrm{H}), 3.24-3.18(\mathrm{~m}, 1 \mathrm{H}), 3.03(\mathrm{dd}, J=12.7,9.4 \mathrm{~Hz}, 1 \mathrm{H}), 2.90-$ $2.84(\mathrm{~m}, 1 \mathrm{H}), 2.12-2.04(\mathrm{~m}, 1 \mathrm{H}), 1.91-1.83(\mathrm{~m}, 1 \mathrm{H}), 1.68-1.43(\mathrm{~m}$,
2H). LC-MS $m / z\left(\mathrm{ES}^{+}\right)(\mathrm{M}+\mathrm{H})^{+} 449.0 ; t_{\mathrm{R}}=1.59 \mathrm{~min}$. HPLC method 2. HRMS (ES-TOF): $m / z$ calcd for $\mathrm{C}_{18} \mathrm{H}_{19} \mathrm{~F}_{6} \mathrm{~N}_{6} \mathrm{O} 449.1519$, found $449.1538[\mathrm{M}+\mathrm{H}]^{+}$.

(S)-2-(3-Aminopiperidin-1-yl)-4-((3-(tert-butyl)phenyl)amino)pyrimidine-5-carboxamide Hydrochloride (10). Prepared in analogous manner to 9 using 3-tert-butyl-aniline. Compound isolated as $\mathrm{HCl}$ salt. ${ }^{1} \mathrm{H}$ NMR $\left(400 \mathrm{MHz}, \mathrm{MeOD}-d_{4}\right) \delta 8.54(\mathrm{~s}, 1 \mathrm{H}), 7.72(\mathrm{~s}$, $1 \mathrm{H}), 7.41(\mathrm{~d}, J=7.8 \mathrm{~Hz}, 1 \mathrm{H}), 7.28(\mathrm{t}, J=7.9 \mathrm{~Hz}, 1 \mathrm{H}), 7.14(\mathrm{dd}, J=7.8$, $2.0 \mathrm{~Hz}, 1 \mathrm{H}), 4.62(\mathrm{dd}, J=12.6,3.9 \mathrm{~Hz}, 1 \mathrm{H}), 4.53(\mathrm{~d}, J=13.2 \mathrm{~Hz}, 1 \mathrm{H})$, $3.18-3.12(\mathrm{~m}, 1 \mathrm{H}), 2.96(\mathrm{dd}, J=12.7,9.4 \mathrm{~Hz}, 1 \mathrm{H}), 2.85-2.78(\mathrm{~m}$, $1 \mathrm{H}), 2.07-1.99(\mathrm{~m}, 1 \mathrm{H}), 1.84-1.77(\mathrm{~m}, 1 \mathrm{H}), 1.63-1.39(\mathrm{~m}, 2 \mathrm{H}), 1.36$ $(\mathrm{s}, 9 \mathrm{H})$; LC-MS $m / z\left(\mathrm{ES}^{+}\right)(\mathrm{M}+\mathrm{H})^{+} 369 ; t_{\mathrm{R}}=2.01 \mathrm{~min}$. HPLC method 2. HRMS (ES-TOF): $m / z$ calcd for $\mathrm{C}_{20} \mathrm{H}_{29} \mathrm{~N}_{6} \mathrm{O} 369.2397$, found $369.2412[\mathrm{M}+\mathrm{H}]^{+}$.

(S)-2-(3-Aminopiperidin-1-yl)-4-((3-(methylsulfonyl)phenyl)amino)pyrimidine-5-carboxamide (11). Prepared in analogous manner to 9 using 3-methylsulfonyl-aniline. ${ }^{1} \mathrm{H}$ NMR (400 $\left.\mathrm{MHz}, \mathrm{MeOD}-d_{4}\right) \delta 9.08(\mathrm{~s}, 1 \mathrm{H}), 8.61(\mathrm{~s}, 1 \mathrm{H}), 7.67-7.55(\mathrm{~m}, 2 \mathrm{H}), 7.49$ $(\mathrm{s}, 1 \mathrm{H}), 4.78(\mathrm{~s}, 1 \mathrm{H}), 4.62(\mathrm{~s}, 1 \mathrm{H}), 3.16-3.10(\mathrm{~m}, 4 \mathrm{H}), 2.99-2.92(\mathrm{~m}$, $2 \mathrm{H}), 2.09(\mathrm{br} \mathrm{s}, 1 \mathrm{H}), 1.89-1.86(\mathrm{~m}, 1 \mathrm{H}), 1.65-1.59(\mathrm{~m}, 1 \mathrm{H}), 1.53-$ $1.44(\mathrm{~m}, 1 \mathrm{H}) ; \mathrm{LC}-\mathrm{MS} m / z\left(\mathrm{ES}^{+}\right)(\mathrm{M}+\mathrm{H})^{+} 391 ; t_{\mathrm{R}}=1.30 \mathrm{~min}$. HPLC method 2. HRMS (ES-TOF): $m / z$ calcd for $\mathrm{C}_{17} \mathrm{H}_{23} \mathrm{~N}_{6} \mathrm{O}_{3} \mathrm{~S} 391.1547$, found $391.1554[\mathrm{M}+\mathrm{H}]^{+}$.

(S)-4-([1,1'-Biphenyl]-3-ylamino)-2-(3-aminopiperidin-1-yl)pyrimidine-5-carboxamide Hydrochloride (12). Prepared in analogous manner to 9 using 3-amino-1,1'-biphenyl. Compound isolated as $\mathrm{HCl}$ salt. ${ }^{1} \mathrm{H}$ NMR $\left(400 \mathrm{MHz}, \mathrm{MeOD}-d_{4}\right) \delta 8.55(\mathrm{~s}, 1 \mathrm{H})$, $7.83(\mathrm{br} \mathrm{s}, 1 \mathrm{H}), 7.64-7.61(\mathrm{~m}, 3 \mathrm{H}), 7.56-7.51(\mathrm{~m}, 2 \mathrm{H}), 7.46(\mathrm{t}, J=7.6$ $\mathrm{Hz}, 2 \mathrm{H}), 7.39-7.35(\mathrm{~m}, 1 \mathrm{H}), 4.34(\mathrm{dd}, J=13.8,3.5 \mathrm{~Hz}, 1 \mathrm{H}), 4.04(\mathrm{br} \mathrm{s}$, $1 \mathrm{H}), 3.78-3.70(\mathrm{~m}, 1 \mathrm{H}), 3.63-3.54(\mathrm{~m}, 1 \mathrm{H}), 3.54-3.47(\mathrm{~m}, 2 \mathrm{H})$, $2.23-2.16(\mathrm{~m}, 1 \mathrm{H}), 1.99-1.89(\mathrm{~m}, 1 \mathrm{H}), 1.89-1.73(\mathrm{~m}, 2 \mathrm{H}$; LC-MS $m / z\left(\mathrm{ES}^{+}\right)(\mathrm{M}+\mathrm{H})^{+} 389.1 ; t_{\mathrm{R}}=2.25$ min. HPLC method 1 . HRMS (ES-TOF): $m / z$ calcd for $\mathrm{C}_{22} \mathrm{H}_{25} \mathrm{~N}_{6} \mathrm{O} 389.2084$, found $389.2101[\mathrm{M}+$ $\mathrm{H}]^{+}$.

(S)-2-(3-Aminopiperidin-1-yl)-4-((3-(2-cyanopropan-2-yl)phenyl)amino)pyrimidine-5-carboxamide (13). Prepared in analogous manner to 9 using 2-(3-aminophenyl)-2-methylpropanenitrile. ${ }^{1} \mathrm{H}$ NMR $\left(400 \mathrm{MHz}, \mathrm{MeOD}-d_{4}\right) 8.56(\mathrm{~s}, 1 \mathrm{H}), 8.08$ (app. t, $J=2.0$ $\mathrm{Hz}, 1 \mathrm{H}), 7.47-7.36(\mathrm{~m}, 2 \mathrm{H}), 7.21$ (ddd, $J=7.4,2.0,1.3 \mathrm{~Hz}, 1 \mathrm{H}), 4.67-$ $4.60(\mathrm{~m}, 1 \mathrm{H}), 4.54(\mathrm{~d}, J=13.2 \mathrm{~Hz}, 1 \mathrm{H}), 3.19-3.09(\mathrm{~m}, 1 \mathrm{H}), 2.96(\mathrm{dd}, J$ $=12.7,9.4 \mathrm{~Hz}, 1 \mathrm{H}), 2.81-2.79(\mathrm{~m}, 1 \mathrm{H}), 2.03(\mathrm{br} \mathrm{s}, 1 \mathrm{H}), 1.84(\mathrm{br} \mathrm{s}$, $1 \mathrm{H}), 1.77(\mathrm{~s}, 6 \mathrm{H}), 1.64-1.52(\mathrm{~m}, 1 \mathrm{H}), 1.49-1.36(\mathrm{~m}, 1 \mathrm{H})$; LC-MS $\mathrm{m} /$ $z\left(\mathrm{ES}^{+}\right)(\mathrm{M}+\mathrm{H})^{+} 380.0 ; t_{\mathrm{R}}=1.66 \mathrm{~min}$. HPLC method 2. HRMS (ESTOF): $m / z$ calcd for $\mathrm{C}_{20} \mathrm{H}_{25} \mathrm{~N}_{7} \mathrm{ONa} 402.2013$, found $402.2016[\mathrm{M}+$ $\mathrm{Na}]^{+}$.

(S)-2-(3-Aminopiperidin-1-yl)-4-((3,5-di-tert-butylphenyl)amino)pyrimidine-5-carboxamide (14). Prepared in analogous manner to 9 using 3,5-di-tert-butyl-aniline. ${ }^{1} \mathrm{H}$ NMR $(400 \mathrm{MHz}$, 
MeOD- $\left.d_{4}\right) \delta 8.53(\mathrm{~s}, 1 \mathrm{H}), 7.43(\mathrm{~d}, J=1.7 \mathrm{~Hz}, 2 \mathrm{H}), 7.38(\mathrm{t}, J=1.7 \mathrm{~Hz}$, $1 \mathrm{H}), 4.27(\mathrm{dd}, J=13.6,3.5 \mathrm{~Hz}, 1 \mathrm{H}), 4.11(\mathrm{br} \mathrm{s}, 1 \mathrm{H}), 3.85-3.74(\mathrm{~m}$, $1 \mathrm{H}), 3.69-3.60(\mathrm{~m}, 1 \mathrm{H}), 3.54-3.46(\mathrm{~m}, 1 \mathrm{H}), 2.23-2.14(\mathrm{~m}, 1 \mathrm{H})$, $1.98-1.89(\mathrm{~m}, 1 \mathrm{H}), 1.89-1.73(\mathrm{~m}, 2 \mathrm{H}), 1.35(\mathrm{~s}, 18 \mathrm{H})$; LC-MS $\mathrm{m} / z$ $\left(\mathrm{ES}^{+}\right)(\mathrm{M}+\mathrm{H})^{+} 425.2 ; t_{\mathrm{R}}=2.43 \mathrm{~min}$. HPLC method 1. HRMS (ESTOF): $m / z$ calcd for $\mathrm{C}_{24} \mathrm{H}_{37} \mathrm{~N}_{6} \mathrm{O} 425.3023$, found $425.3036[\mathrm{M}+\mathrm{H}]^{+}$.

(S)-2-(3-Aminopiperidin-1-yl)-4-((3,5-diisopropylphenyl)amino)pyrimidine-5-carboxamide (15). Step 1: 1-Nitro-3,5-di(prop-1-en-2-yl)benzene. A mixture of 1,3-dibromo-5-nitrobenzene $(2.0 \mathrm{~g}, 7.14 \mathrm{mmol}), 4,4,5,5$-tetramethyl-2-(1-methylethenyl)-1,3,2dioxaborolane (3.6 g, $21.42 \mathrm{mmol}), \mathrm{Pd}\left(\mathrm{PPh}_{3}\right)_{4}(164 \mathrm{mg}, 0.142 \mathrm{mmol})$, and $\mathrm{K}_{2} \mathrm{CO}_{3}(3.0 \mathrm{~g}, 21.4 \mathrm{mmol})$ was heated at $100{ }^{\circ} \mathrm{C}$ in dioxane $-\mathrm{H}_{2} \mathrm{O}$ $\left(100 \mathrm{~mL}\right.$ ) with stirring under $\mathrm{N}_{2}$. After cooling, the reaction was quenched with saturated aq. $\mathrm{NH}_{4} \mathrm{Cl}$ solution, extracted with EtOAc, dried over $\mathrm{Na}_{2} \mathrm{SO}_{4}$, filtered, and evaporated. The residue was chromatographed on $\mathrm{SiO}_{2}$ gel using $\mathrm{CH}_{2} \mathrm{Cl}_{2}$-hexane gradient elution to afford the pure title compound $(1.20 \mathrm{~g}, 83 \%)$. LC $t_{\mathrm{R}} 3.22 \mathrm{~min}(>95 \%$; method 1).

Step 2: 3,5-Diisopropylaniline (27). The material from the previous step $(1.2 \mathrm{~g}, 5.9 \mathrm{mmol})$ was dissolved in $\mathrm{MeOH}(20 \mathrm{~mL})$. The solution was stirred, purged with $\mathrm{N}_{2}$, and then treated with $\mathrm{H}_{2}$ over $\operatorname{Pd}(\mathrm{C})$ overnight. The catalyst was removed by filtration, and the solution was evaporated. The residue of title compound $(1.02 \mathrm{~g}, 98 \%)$ was used in the next step without further purification. LC-MS $m / z\left(\mathrm{ES}^{+}\right)$177.7 [M $+\mathrm{H}]^{+} ; t_{\mathrm{R}} 2.47 \min (\operatorname{method} 1)$.

Step 3: 2-Chloro-4-((3,5-diisopropylphenyl)amino)pyrimidine-5carboxamide. The material from the previous step (1.02 g, 5.75 $\mathrm{mmol})$, 2,4-dichloropyrimidine-5-carboxamide $(1.2 \mathrm{~g}, 6.2 \mathrm{mmol})$, and ${ }_{i P r} \mathrm{NEt}(1.3 \mathrm{~mL})$ were dissolved in $\mathrm{MeCN}(20 \mathrm{~mL})$, and the mixture was heated under reflux for $3 \mathrm{~h}$. The resulting solution was evaporated, redissolved in the minimum volume of $\mathrm{CH}_{2} \mathrm{Cl}_{2}$, and chromatographed on $\mathrm{SiO}_{2}$ gel using $\mathrm{CH}_{2} \mathrm{Cl}_{2}-\mathrm{EtOAc}$ gradient elution. Fractions containing pure title product were pooled, evaporated, and triturated with $\mathrm{Et}_{2} \mathrm{O}(1.34 \mathrm{~g}, 71 \%)$. LC-MS $\left(\mathrm{ES}^{+}\right) t_{\mathrm{R}} 3.18 \mathrm{~min}$ (>95\%; method 1), $m / z 332.8[\mathrm{M}+\mathrm{H}]^{+}$.

Step 4: tert-Butyl (S)-(1-(5-Carbamoyl-4-((3,5-diisopropylphenyl)amino)pyrimidin-2-yl)piperidin-3-yl)carbamate. The material from the previous step $(66 \mathrm{mg}, 0.20 \mathrm{mmol})$ was reacted with tert-butyl $(S)$ piperidin-3-ylcarbamate $(44 \mathrm{mg}, 0.22 \mathrm{mmol})$ and $\mathrm{iPr}_{2} \mathrm{NEt}(0.1 \mathrm{~mL})$ by stirring in $\mathrm{MeCN}(3 \mathrm{~mL})$ at $50{ }^{\circ} \mathrm{C}$ for $20 \mathrm{~h}$. After cooling, the reaction mixture was evaporated, diluted with $\mathrm{H}_{2} \mathrm{O}$, extracted with $\mathrm{CH}_{2} \mathrm{Cl}_{2}$, dried over $\mathrm{Na}_{2} \mathrm{SO}_{4}$, filtered, and evaporated. The residue was chromatographed on $\mathrm{SiO}_{2}$ gel using $\mathrm{CH}_{2} \mathrm{Cl}_{2}-\mathrm{EtOAc}$ gradient elution to afford the pure title compound $(74 \mathrm{mg}, 75 \%)$. LC-MS $\left(\mathrm{ES}^{+}\right) t_{\mathrm{R}} 3.08$ min (91\%; method 1$), m / z 497.8[\mathrm{M}+\mathrm{H}]^{+}$.

Step 5: (S)-2-(3-Aminopiperidin-1-yl)-4-((3,5-diisopropylphenyl)amino)pyrimidine-5-carboxamide (16). The material from the previous step $(74 \mathrm{mg}, 0.149 \mathrm{mmol})$ was treated with excess $\mathrm{HCl}$ in dioxane at room temperature for $4 \mathrm{~h}$ to afford the title compound ( 55 $\mathrm{mg}, 92.6 \%)$ after evaporation and trituration with $\mathrm{Et}_{2} \mathrm{O} .{ }^{1} \mathrm{H}$ NMR (400 MHz, DMSO- $\left.d_{6}\right) \delta 8.67(\mathrm{~s}, 1 \mathrm{H}), 7.25(\mathrm{~s}, 2 \mathrm{H}), 7.00(\mathrm{~s}, 1 \mathrm{H}), 4.16(\mathrm{~m}$, $1 \mathrm{H}), 3.03-3.25(\mathrm{~m}, 3 \mathrm{H}), 2.88(\mathrm{~m}, 3 \mathrm{H}), 1.85-2.06(\mathrm{~m}, 2 \mathrm{H}), 1.68(\mathrm{~m}, 2$ H), 1.18 (app. dd, $J=7.0 \mathrm{~Hz}, 1.2 \mathrm{~Hz}, 12 \mathrm{H}$ ); LC-MS $\left(\mathrm{ES}^{+}\right) t_{\mathrm{R}} 2.36 \mathrm{~min}$ (87.2\%, method 1 ), $m / z 397.0[\mathrm{M}+\mathrm{H}]^{+}$. HRMS (ES-TOF): $m / z$ calcd for $\mathrm{C}_{22} \mathrm{H}_{33} \mathrm{~N}_{6} \mathrm{O}$ 397.2710, found 397.2723 $[\mathrm{M}+\mathrm{H}]^{+}$.

(S)-2-(3-Aminopiperidin-1-yl)-4-((3-(tert-butyl)-5(methylsulfonyl)phenyl)amino)pyrimidine-5-carboxamide (16). Step 1: 3-(tert-Butyl)-5-nitrobenzenesulfonyl Chloride (30). To a solution of 1-(tert-butyl)-3-nitrobenzene $(179 \mathrm{mg}, 1 \mathrm{mmol})$ in $\mathrm{CHCl}_{3}$ $(15 \mathrm{~mL})$, chlorosulfonic acid $(167 \mu \mathrm{L}, 2.5 \mathrm{mmol})$ was added in one portion, and the mixture stirred at reflux for $48 \mathrm{~h}$. Upon complete consumption of the starting material, water $(15 \mathrm{~mL})$ and DCM (15 $\mathrm{mL}$ ) were added, the crude was partitioned, the aqueous layer extracted with DCM $(2 \times 20 \mathrm{~mL})$, and the combined organic layers were washed with brine, dried with $\mathrm{MgSO}_{4}$, and condensed. The crude was purified by flash column chromatography (gradient: hexane/ethyl acetate $=9: 1$ to $3: 1)$ to give the desired product as a brown oil $(235 \mathrm{mg}, 85 \%) .{ }^{1} \mathrm{H}$ $\operatorname{NMR}\left(300 \mathrm{MHz}, \mathrm{CDCl}_{3}\right) \delta 8.73(\mathrm{t}, J=1.9 \mathrm{~Hz}, 1 \mathrm{H}), 8.62(\mathrm{t}, J=1.9 \mathrm{~Hz}$, $1 \mathrm{H}), 8.35(\mathrm{t}, J=1.9 \mathrm{~Hz}, 1 \mathrm{H}), 1.48(\mathrm{~s}, 9 \mathrm{H})$; $\mathrm{MS} \mathrm{m} / z(\mathrm{ES})[\mathrm{M}+\mathrm{Na}]^{+}$ 300.0 .
Step 2: 3-(tert-Butyl)-5-nitrobenzenethiol (31). To a solution of 3(tert-butyl)-5-nitrobenzenesulfonyl chloride $(0.28 \mathrm{~g}, 1.0 \mathrm{mmol})$ in toluene $(8 \mathrm{~mL})$, triphenyl phosphine $(0.79 \mathrm{mg}, 3.0 \mathrm{mmol})$ was added portionwise, and the reaction was stirred at room temperature for 10 min. Upon complete consumption of the starting material, water (4 $\mathrm{mL}$ ) was added, and the mixture was partitioned. The organic layer was extracted with aqueous $\mathrm{NaOH}(10 \%, 2 \times 15 \mathrm{~mL})$, and the aqueous layer was washed AcOEt $(2 \times 15 \mathrm{~mL})$, acidified with concentrated $\mathrm{HCl}$ and extracted with $\mathrm{CH}_{2} \mathrm{Cl}_{2}(2 \times 15 \mathrm{~mL})$. The combined organic layers were dried with $\mathrm{MgSO}_{4}$ and condensed to give the desired product as a clear oil $(0.15 \mathrm{~g}, 72 \%) .{ }^{1} \mathrm{H}$ NMR $\left(400 \mathrm{MHz}, \mathrm{CDCl}_{3}\right) \delta 7.94$ (app.t, $J=$ $1.9 \mathrm{~Hz}, 1 \mathrm{H}$ ), 7.87 (app. t, $J=1.9 \mathrm{~Hz}, 1 \mathrm{H}), 7.49$ (app.t, $J=1.9 \mathrm{~Hz}, 1 \mathrm{H}$ ), $3.62(\mathrm{~s}, 1 \mathrm{H}), 1.27(\mathrm{~s}, 9 \mathrm{H}) ;{ }^{13} \mathrm{C} \mathrm{NMR}\left(101 \mathrm{MHz}, \mathrm{CDCl}_{3}\right) \delta 177.5$, 154.1, 133.1, 132.0, 121.0, 117.9, 35.2, 31.0; MS $m / z$ (ES) $[\mathrm{M}]^{+} 211.1$.

Step 3: (3-(tert-Butyl)-5-nitrophenyl)(methyl)sulfane (32). To a solution of 3-(tert-butyl)-5-nitrobenzenethiol $(210 \mathrm{mg}, 1.0 \mathrm{mmol})$ in EtOH ( $5 \mathrm{~mL}), \mathrm{NaOH}(48 \mathrm{mg}, 1.2 \mathrm{mmol}$ ) was added, and the mixture was stirred at RT for $2 \mathrm{~h}$. Methyl iodide $(69 \mu \mathrm{L}, 1.1 \mathrm{mmol})$ was added, and the mixture was left to react overnight. The reaction was partitioned between water and AcOEt and extracted with AcOEt $(2 \times 10 \mathrm{~mL})$, and the combined organic layers were washed with brine $(1 \times 15 \mathrm{~mL})$, dried with $\mathrm{MgSO}_{4}$, and condensed. The crude was purified by flash column chromatography (gradient hexane/AcOEt, 5:1 to 3:1) to give the desired product as a colorless oil $(220 \mathrm{mg}, 98 \%) .{ }^{1} \mathrm{H}$ NMR $(300 \mathrm{MHz}$, $\left.\mathrm{CDCl}_{3}\right) \delta 7.92$ (app. t, $\left.J=1.8 \mathrm{~Hz}, 1 \mathrm{H}\right), 7.79$ (app. t, $J=1.8 \mathrm{~Hz}, 1 \mathrm{H}$ ), 7.48 (app. t, $J=1.8 \mathrm{~Hz}, 1 \mathrm{H}), 2.49$ (s, 3H), 1.28 (s, 9H).

Step 4: 1-(tert-Butyl)-3-(methylsulfonyl)-5-nitrobenzene (33). To a solution of (3-(tert-butyl)-5-nitrophenyl)(methyl)sulfane (0.42 g, $1.88 \mathrm{mmol})$ in $\mathrm{CH}_{2} \mathrm{Cl}_{2}(4 \mathrm{~mL})$ at $0{ }^{\circ} \mathrm{C}, \mathrm{mCPBA}(1.10 \mathrm{~g}, 4.70 \mathrm{mmol})$ was added in one portion at room temperature. The mixture was left to warm up to room temperature and react for $2 \mathrm{~h}$. Upon complete consumption of the starting material, the mixture was washed with $\mathrm{NaHCO}_{3}(2 \times 10 \mathrm{~mL})$ and brine $(10 \mathrm{~mL})$, dried with $\mathrm{MgSO}_{4}$, and condensed. The crude was purified by flash column chromatography (gradient hexane/AcOEt, 4:1 to 2:1) to give the desired product as a white solid (333 mg, 73\%). ${ }^{1} \mathrm{H}$ NMR $\left(300 \mathrm{MHz}, \mathrm{CDCl}_{3}\right) \delta 8.64-8.58$ $(\mathrm{m}, 1 \mathrm{H}), 8.52$ (app. t, $J=1.9 \mathrm{~Hz}, 1 \mathrm{H}), 8.28$ (app. t, $J=1.9 \mathrm{~Hz}, 1 \mathrm{H}), 3.16$ $(\mathrm{s}, 3 \mathrm{H}), 1.44(\mathrm{~s}, 9 \mathrm{H})$.

Step 5: 3-(tert-Butyl)-5-(methylsulfonyl)aniline (34). A solution of 1-(tert-butyl)-3-(methylsulfonyl)-5-nitrobenzene (333 mg, $1.3 \mathrm{mmol}$ ) and palladium on carbon $(10 \mathrm{~mol} \%)$ in $\mathrm{MeOH}(6 \mathrm{~mL})$ was stirred overnight under $5 \mathrm{~atm}$ of hydrogen. The mixture was thereafter filtered through Celite, solvents were evaporated, and the crude was purified by flash column chromatography (gradient hexane/AcOEt, 4:1 to 2:1) to give the desired product as a white solid $(230 \mathrm{mg}, 76 \%) .{ }^{1} \mathrm{H}$ NMR $(300$ $\left.\mathrm{MHz}, \mathrm{CDCl}_{3}\right) \delta 7.31$ (app. t, $\left.J=1.6 \mathrm{~Hz}, 1 \mathrm{H}\right), 7.05(\mathrm{dd}, J=2.1,1.7 \mathrm{~Hz}$, $1 \mathrm{H}), 6.95-6.93(\mathrm{~m}, 1 \mathrm{H}), 4.02(\mathrm{~s}, 1 \mathrm{H}), 3.04(\mathrm{~s}, 3 \mathrm{H}), 1.32(\mathrm{~s}, 9 \mathrm{H})$; MS $\mathrm{m} / z(\mathrm{ES})[\mathrm{MH}]^{+} 228.1$.

Step 6: (S)-2-(3-Aminopiperidin-1-yl)-4-((3-(tert-butyl)-5(methylsulfonyl)phenyl)-amino) pyrimidine-5-carboxamide (16). Prepared in analogous manner to 9 using 3-(tert-butyl)-5(methylsulfonyl)aniline (32 mg, 10\%). ${ }^{1} \mathrm{H}$ NMR (400 MHz, MeOD$\left.d_{4}\right) \delta 8.79(\mathrm{~s}, 1 \mathrm{H}), 8.62(\mathrm{~s}, 1 \mathrm{H}), 7.68($ app. $\mathrm{t}, J=1.6 \mathrm{~Hz}, 1 \mathrm{H}), 7.55(\mathrm{~s}$, $1 \mathrm{H}), 4.71(\mathrm{~s}, 1 \mathrm{H}), 4.38(\mathrm{~d}, J=11.8 \mathrm{~Hz}, 1 \mathrm{H}), 3.60-3.36(\mathrm{~m}, 3 \mathrm{H}), 3.21$ $(\mathrm{s}, 3 \mathrm{H}), 2.21(\mathrm{~d}, J=4.3 \mathrm{~Hz}, 1 \mathrm{H}), 1.93(\mathrm{dd}, J=10.3,5.0 \mathrm{~Hz}, 1 \mathrm{H}), 1.86-$ $1.65(\mathrm{~m}, 2 \mathrm{H}), 1.40(\mathrm{~s}, 9 \mathrm{H})$. HRMS (ES-TOF): $\mathrm{m} / z$ calcd for $\mathrm{C}_{21} \mathrm{H}_{30} \mathrm{~N}_{6} \mathrm{O}_{3} \mathrm{~S} 447.2178$, found $447.2174[\mathrm{M}+\mathrm{H}]^{+}$.

(S)-2-(3-Aminopiperidin-1-yl)-4-((5-(2-cyanopropan-2-yl)[1,1'-biphenyl]-3-yl)amino)pyrimidine -5-carboxamide Hydrochloride (17). Step 1: N,N-Dibenzyl-3,5-dibromoaniline (35). To 3,5-dibromoaniline $(2.50 \mathrm{~g}, 9.96 \mathrm{mmol})$, potassium carbonate (4.13 $\mathrm{g}, 29.88 \mathrm{mmol})$, and benzyl bromide $(3.55 \mathrm{~mL}, 29.89 \mathrm{mmol}$ ) was added $\mathrm{MeCN}(40 \mathrm{~mL})$. The mixture was heated to reflux and left to stir overnight. After allowing the mixture to cool to $\mathrm{RT}, \mathrm{MeCN}$ was removed under reduced pressure, and AcOEt $(60 \mathrm{~mL})$ was added. The organic solution was washed with water $(3 \times 50 \mathrm{~mL})$, dried over $\mathrm{MgSO}_{4}$, filtered, and concentrated under reduced pressure to give the crude product, which was purified first by flash column chromatography (95:5 hexane/AcOEt) and then by recrystallization from boiling hot hexane with a small amount of AcOEt (filtered while hot and left to 
cool) to give the title compound as a white solid $(3.13 \mathrm{~g}, 73 \%) .{ }^{1} \mathrm{H}$ $\operatorname{NMR}\left(400 \mathrm{MHz}, \mathrm{CDCl}_{3}\right) \delta 7.35$ (app.t, $\left.J=7.2 \mathrm{~Hz}, 4 \mathrm{H}\right), 7.31-7.25(\mathrm{~m}$, $2 \mathrm{H}), 7.19(\mathrm{~d}, J=7.6 \mathrm{~Hz}, 4 \mathrm{H}), 6.97(\mathrm{~s}, 1 \mathrm{H}), 6.79(\mathrm{~s}, 2 \mathrm{H}), 4.59(\mathrm{~s}, 4 \mathrm{H})$; LC-MS $m / z(\mathrm{ES}+)(\mathrm{M}+\mathrm{H})^{+} 431.8 ; t_{\mathrm{R}}=3.24 \mathrm{~min}$. HPLC method 3 (acid).

Step 2: 2-(3-Bromo-5-(dibenzylamino)phenyl)-2-methylpropanenitrile (37). N,N-Dibenzyl-3,5-dibromoaniline $51(1.00 \mathrm{~g}, 2.32 \mathrm{mmol})$, Xantphos (0.16 g, $0.28 \mathrm{mmol}), \mathrm{Pd}_{2}$ allyl $_{2} \mathrm{Cl}_{2}(0.04 \mathrm{~g}, 4 \mathrm{~mol} \%)$, and potassium 2-cyano-2-methylpropanoate $(0.84 \mathrm{~g}$, $5.55 \mathrm{mmol})$ were added to a pressure vessel, which was flushed with $\mathrm{N}_{2}$ through a septum for $15 \mathrm{~min}$. Mesitylene $(5.5 \mathrm{~mL})$ was introduced, the septum was quickly replaced with a screwcap, and the mixture was stirred vigorously for $5 \mathrm{~min}$ at RT. The flask was lowered into an oil bath preheated to 140 ${ }^{\circ} \mathrm{C}$ and left to stir vigorously overnight. Following cooling, the crude reaction mixture was transferred to a round bottomed flask with the aid of AcOEt $(20 \mathrm{~mL})$ and concentrated under reduced pressure. The resulting residue was purified by flash column chromatography on silica (gradient hexane, then 7:1 hexane/AcOEt followed by 6:1 and finally $5: 1)$ to give

- 2,2'-(5-(dibenzylamino)-1,3-phenylene)bis(2-methylpropanenitrile) (36) isolated as a light-yellow oil, which solidified on standing (0.50 g, 53\%). ${ }^{1} \mathrm{H}$ NMR $\left(400 \mathrm{MHz}, \mathrm{CDCl}_{3}\right) \delta 7.34$ (app. t, $J=7.6 \mathrm{~Hz}, 4 \mathrm{H}), 7.31-7.22(\mathrm{~m}, 6 \mathrm{H}), 6.83(\mathrm{~s}, 1 \mathrm{H}), 6.75$ $(\mathrm{d}, J=2.0 \mathrm{~Hz}, 2 \mathrm{H}), 4.70(\mathrm{~s}, 4 \mathrm{H}), 1.60(\mathrm{~s}, 12 \mathrm{H}) ; \mathrm{LC}-\mathrm{MS} m / z(\mathrm{ES}$ +) $(\mathrm{M}+\mathrm{H})^{+} 408.3 ; t_{\mathrm{R}}=2.88 \mathrm{~min}$. HPLC method 3 (acid).

- 2-(3-bromo-5-(dibenzylamino)phenyl)-2-methylpropanenitrile (37) isolated as a light-yellow oil, which solidified on standing $(0.20 \mathrm{~g}, 20 \%) .{ }^{1} \mathrm{H}$ NMR $\left(400 \mathrm{MHz}, \mathrm{CDCl}_{3}\right) \delta 7.40-7.33(\mathrm{~m}$, $4 \mathrm{H}), 7.32-7.23(\mathrm{~m}, 6 \mathrm{H}), 6.90$ (app. $\mathrm{t}, J=1.6 \mathrm{~Hz}, 1 \mathrm{H}), 6.85$ (dd, $J=2.4,1.6 \mathrm{~Hz}, 1 \mathrm{H}), 6.73$ (app. t, $J=2.0 \mathrm{~Hz}, 1 \mathrm{H}), 4.67(\mathrm{~s}, 4 \mathrm{H})$, $1.58(\mathrm{~s}, 6 \mathrm{H})$; LC-MS $m / z(\mathrm{M}+\mathrm{H})^{+}\left(\mathrm{ES}^{+}\right) 419.3,421.2 ; t_{\mathrm{R}}=$ 3.14 min. HPLC method 2 (base).

Step 3: 2-(5-(Dibenzylamino)-[1,1'-biphenyl]-3-yl)-2-methylpropanenitrile (39). A stirred solution of potassium carbonate $(0.20 \mathrm{~g}, 1.44$ $\mathrm{mmol}$ ), phenyl-4,4,5,5-tetramethyl-1,3,2-dioxaborolane (0.15 g, 0.71 $\mathrm{mmol}$ ), and 2-(3-bromo-5-(dibenzylamino)phenyl)-2-methylpropanenitrile $53(0.20 \mathrm{~g}, 0.48 \mathrm{mmol})$ in 1,4-dioxane $(8 \mathrm{~mL})$ and water $(2 \mathrm{~mL})$ was purged with nitrogen for $10 \mathrm{~min}$. $\mathrm{PdCl}_{2}\left(\mathrm{PPh}_{3}\right)_{2}(34 \mathrm{mg}, 0.05$ $\mathrm{mmol}$ ) was added and purging was continued for a further $10 \mathrm{~min}$. The reaction was then heated $100{ }^{\circ} \mathrm{C}$ and stirred under nitrogen for $1 \mathrm{~h}$. Upon cooling, the solution was diluted with water $(20 \mathrm{~mL})$ and extracted with ethyl acetate $(3 \times 20 \mathrm{~mL})$. The combined organic layers were dried over $\mathrm{MgSO}_{4}$, filtered, and concentrated under vacuum. The crude product was purified by chromatography on silica gel $(20 \%$ AcOEt in hexane) to afford the titled product $(0.14 \mathrm{~g}, 74 \%) .{ }^{1} \mathrm{H}$ NMR $\left(400 \mathrm{MHz}, \mathrm{CDCl}_{3}\right) \delta 7.52-7.44(\mathrm{~m}, 2 \mathrm{H}), 7.44-7.25(\mathrm{~m}, 13 \mathrm{H}), 7.02$ $(\mathrm{d}, J=1.5 \mathrm{~Hz}, 1 \mathrm{H}), 6.92($ app. $\mathrm{t}, J=1.9 \mathrm{~Hz}, 1 \mathrm{H}), 6.82($ app. $\mathrm{t}, J=2.1 \mathrm{~Hz}$, $1 \mathrm{H}), 4.75(\mathrm{~s}, 4 \mathrm{H}), 1.66(\mathrm{~s}, 6 \mathrm{H})$; LC-MS $m / z(\mathrm{M}+\mathrm{H})^{+}\left(\mathrm{ES}^{+}\right)$417.3; $t_{\mathrm{R}}$ $=3.14$ min. HPLC method 2 (base).

Step 4: 2-(5-Amino-[1,1'-biphenyl]-3-yl)-2-methylpropanenitrile (40). 2-(5-(Dibenzylamino)-[1,1'-biphenyl]-3-yl)-2-methylpropanenitrile $54(0.14 \mathrm{~g}, 0.34 \mathrm{mmol})$ was introduced to a flask, which was flushed with $\mathrm{N}_{2}$ for 10 min. $\mathrm{Pd}(\mathrm{OH})_{2}(0.04 \mathrm{~g}, 10-20 \% \mathrm{Pd}$ basis $), \mathrm{CH}_{2} \mathrm{Cl}_{2}(3.0$ $\mathrm{mL})$, and finally $\mathrm{MeOH}(3.0 \mathrm{~mL})$ were added, and the flask was purged with $\mathrm{H}_{2}$. The mixture was left to stir vigorously at $\mathrm{RT}$ for $1 \mathrm{~h}$ after which the flask was opened to the air, and the mixture was filtered through a pad of Celite under reduced pressure. The cake was washed with additional $\mathrm{MeOH}(30 \mathrm{~mL})$ and $\mathrm{CH}_{2} \mathrm{Cl}_{2}(30 \mathrm{~mL})$, the filtrate was concentrated under reduced pressure, and the crude product was purified by flash column chromatography on silica (20\% AcOEt in hexane) to give the title compound as a colorless oil $(60 \mathrm{mg}, 88 \%) .{ }^{1} \mathrm{H}$ NMR $\left(400 \mathrm{MHz}, \mathrm{CDCl}_{3}\right) \delta 7.61-7.54(\mathrm{~m}, 2 \mathrm{H}), 7.51-7.42(\mathrm{~m}, 2 \mathrm{H})$, $7.41-7.35(\mathrm{~m}, 1 \mathrm{H}), 7.05$ (app. $\mathrm{t}, J=1.6 \mathrm{~Hz}, 1 \mathrm{H}), 6.86$ (app. $\mathrm{t}, J=1.8$ $\mathrm{Hz}, 1 \mathrm{H}), 6.82$ (app. t, $J=2.0 \mathrm{~Hz}, 1 \mathrm{H}), 1.77$ (s, 6H); LC-MS $m / z(\mathrm{M}+$ $\mathrm{H})^{+}\left(\mathrm{ES}^{+}\right) 237.2 ; t_{\mathrm{R}}=2.42$ min. HPLC method 2 (base).

(S)-2-(3-Aminopiperidin-1-yl)-4-((5-(2-cyanopropan-2-yl)-[1,1'biphenyl]-3-yl)amino)pyrimidine-5-carboxamide Hydrochloride (20). Compound 20 was prepared in analogous manner to 9 using 2(5-amino-[1,1'-biphenyl]-3-yl)-2-methylpropanenitrile $\mathbf{4 0}$ and isolated as $\mathrm{HCl}$ salt $(30 \mathrm{mg}, 73 \%) .{ }^{1} \mathrm{H}$ NMR $\left(400 \mathrm{MHz}, \mathrm{MeOD}-d_{4}\right) \delta 8.61$ (s,
$1 \mathrm{H}$ ), 8.04 (br. s, $1 \mathrm{H}), 7.72$ (br. s, 1H), 7.70-7.66 (m, 2H), 7.62 (app.t, $J=1.7 \mathrm{~Hz}, 1 \mathrm{H}), 7.54-7.49(\mathrm{~m}, 2 \mathrm{H}), 7.46-7.39(\mathrm{~m}, 1 \mathrm{H}), 4.42$ (app. dd, $J=14.0,3.7 \mathrm{~Hz}, 1 \mathrm{H}), 4.08$ (br. s, $1 \mathrm{H}), 3.82($ br. s, $1 \mathrm{H}), 3.69-3.60(\mathrm{~m}$, $1 \mathrm{H}), 3.57-3.48(\mathrm{~m}, 1 \mathrm{H}), 2.27-2.14(\mathrm{~m}, 1 \mathrm{H}), 2.05-1.94(\mathrm{~m}, 1 \mathrm{H})$, $1.88-1.79(\mathrm{~m}, 8 \mathrm{H})$; LC-MS $m / z(\mathrm{M}+\mathrm{H})^{+}\left(\mathrm{ES}^{+}\right) 456.3$; $t_{\mathrm{R}}=2.23 \mathrm{~min}$. HPLC method 2 (base). HRMS (ES-TOF): $m / z$ calcd for $\mathrm{C}_{26} \mathrm{H}_{30} \mathrm{~N}_{7} \mathrm{O}$ 456.2506, found $456.2506[\mathrm{M}+\mathrm{H}]^{+}$.

(S)-2-(3-Aminopiperidin-1-yl)-4-((3,5-bis(2-cyanopropan-2yl)phenyl)amino)pyrimidine-5-carboxamide Hydrochloride (18). Step 1: 2,2'-(5-Amino-1,3-phenylene)bis(2-methylpropanenitrile) (38). 2,2'-(5-(Dibenzylamino)-1,3-phenylene)bis(2-methylpropanenitrile) 36 ( $3.05 \mathrm{~g}, 7.48 \mathrm{mmol})$ was introduced to a flask, which was flushed with $\mathrm{N}_{2}$ for $10 \mathrm{~min}$. $\mathrm{Pd}(\mathrm{OH})_{2}(1.05 \mathrm{~g}, 10-20 \% \mathrm{Pd}$ basis $)$, $\mathrm{CH}_{2} \mathrm{Cl}_{2}(8.0 \mathrm{~mL})$, and finally $\mathrm{MeOH}(30 \mathrm{~mL})$ were added, and the flask was purged with $\mathrm{H}_{2}$. The mixture was left to stir vigorously at $\mathrm{RT}$ for $3 \mathrm{~h}$, after which the flask was opened to the air, and the mixture was filtered through a pad of Celite under reduced pressure. The cake was washed with additional $\mathrm{MeOH}(30 \mathrm{~mL})$ and $\mathrm{CH}_{2} \mathrm{Cl}_{2}(30 \mathrm{~mL})$, the filtrate was concentrated under reduced pressure, and the crude product was purified by flash column chromatography on silica ( $1: 1$ hexane/AcOEt) to give the title compound as a light-yellow oil, which slowly solidified on standing $(1.68 \mathrm{~g}, 98 \%) .{ }^{1} \mathrm{H}$ NMR $\left(400 \mathrm{MHz}, \mathrm{CDCl}_{3}\right) \delta 6.85(\mathrm{t}, J=$ $2.0 \mathrm{~Hz}, 1 \mathrm{H}), 6.73(\mathrm{~d}, J=2.4 \mathrm{~Hz}, 1 \mathrm{H}), 3.36-2.78(\mathrm{br} \mathrm{s}, 2 \mathrm{H}), 1.70(\mathrm{~s}$, $12 \mathrm{H}) ; \mathrm{LC}-\mathrm{MS} m / z(\mathrm{ES}+)(\mathrm{M}+\mathrm{H})^{+} 228.2 ; t_{\mathrm{R}}=2.15 \mathrm{~min}$. HPLC method 3 (acid).

Step 2: (S)-2-(3-Aminopiperidin-1-yl)-4-((3,5-bis(2-cyanopropan2-yl)phenyl)amino)pyrimidine-5-carboxamide Hydrochloride (18). 2,2' -(5-Amino-1,3-phenylene)bis(2-methylpropanenitrile) 38 (0.76 g, $3.36 \mathrm{mmol}$ ), 2,4-dichloropyrimidine-5-carboxamide (0.82 g, 4.28 $\mathrm{mmol})$, and triethylamine $(1.01 \mathrm{~mL}, 7.25 \mathrm{mmol})$ were dissolved in anhydrous dioxane $(35 \mathrm{~mL})$. The mixture was heated at $50{ }^{\circ} \mathrm{C}$ for $3 \mathrm{~h}$ and then left to cool to RT. Additional 2,4-dichloropyrimidine-5carboxamide $(0.06 \mathrm{~g}, 0.32 \mathrm{mmol})$ and triethylamine $(0.09 \mathrm{~mL}, 0.65$ $\mathrm{mmol}$ ) were added, and the mixture was heated to $50{ }^{\circ} \mathrm{C}$ for a further $1.5 \mathrm{~h}$. The reaction mixture was allowed to cool to RT, tert-butyl $(S)$ piperidin-3-ylcarbamate $(0.73 \mathrm{~g}, 3.62 \mathrm{mmol})$ and triethylamine $(1.01$ $\mathrm{mL}, 7.25 \mathrm{mmol}$ ) were added, and the reaction mixture was heated at 50 ${ }^{\circ} \mathrm{C}$ for $75 \mathrm{~min}$. AcOEt $(60 \mathrm{~mL})$ was added, and the solution washed sequentially with water $(5 \times 30 \mathrm{~mL})$ and brine $(30 \mathrm{~mL})$. The organic phase was dried over $\mathrm{MgSO}_{4}$, filtered, and concentrated under reduced pressure to give the crude product from two displacements, which was purified by flash column chromatography (gradient 1:2 to 1:3 hexane/ AcOEt) to give the product from two displacements (1.30 g, 71\%). Dioxane $(30 \mathrm{~mL})$ was added followed by the dropwise addition of $4 \mathrm{M}$ $\mathrm{HCl}$ in dioxane $(15 \mathrm{~mL})$, and the reaction mixture was stirred at $\mathrm{RT}$ for $24 \mathrm{~h}$. Hexane $(30 \mathrm{~mL})$ was added, and the solid was filtered and triturated with $\mathrm{Et}_{2} \mathrm{O}$ to remove residual dioxane. The resulting solid was filtered and dried to give the hydrochloride salt of the title compound as a light-yellow powder $(1.12 \mathrm{~g}, 98 \%)$. Mp $232-233{ }^{\circ} \mathrm{C}$; ${ }^{1} \mathrm{H}$ NMR (400 $\left.\mathrm{MHz}, \mathrm{MeOD}-d_{4}\right) \delta 8.60(\mathrm{~s}, 1 \mathrm{H}), 7.83(\mathrm{~d}, J=1.6 \mathrm{~Hz}, 2 \mathrm{H}), 7.50(\mathrm{t}, J=1.6$ $\mathrm{Hz}, 1 \mathrm{H}), 4.39$ (dd, $J=13.6,3.2 \mathrm{~Hz}, 1 \mathrm{H}), 4.14-3.95(\mathrm{~m}, 1 \mathrm{H}), 3.89-$ $3.77(\mathrm{~m}, 1 \mathrm{H}), 3.68-3.62(\mathrm{~m}, 1 \mathrm{H}), 3.57-3.49(\mathrm{~m}, 1 \mathrm{H}), 2.23-2.13(\mathrm{~m}$, $1 \mathrm{H}), 2.07-1.95(\mathrm{~m}, 1 \mathrm{H}), 1.89-1.80(\mathrm{~m}, 1 \mathrm{H}), 1.79(\mathrm{~s}, 12 \mathrm{H}) ;{ }^{13} \mathrm{C} \mathrm{NMR}$ $\left(126 \mathrm{MHz}, \mathrm{MeOD}-d_{4}\right) \delta 167.2,159.1,152.6,145.0,143.9,137.6,124.1$, $119.1,118.6,101.5,46.4,45.2,37.3,27.8,27.1,21.1$; LC-MS $m / z$ (ES+) $(\mathrm{M}+\mathrm{H})^{+} 447.0 ; t_{\mathrm{R}}=1.91 \mathrm{~min}$. HPLC method 3 (acid). HRMS (ESTOF): $m / z$ calcd for $\mathrm{C}_{24} \mathrm{H}_{31} \mathrm{~N}_{8} \mathrm{O} 447.2615$, found $447.2636[\mathrm{M}+\mathrm{H}]^{+}$.

(S)-2-(3-Aminopiperidin-1-yl)-4-((2,6-diisopropylpyridin-4yl)amino)pyrimidine-5-carboxamide (19). Step 1: 2,6-Di(prop-1en-2-yl)pyridin-4-amine. A stirred solution of sodium bicarbonate $(0.37 \mathrm{~g}, 4.37 \mathrm{mmol}), 4,4,5,5$-tetramethyl-2-(prop-1-en-2-yl)-1,3,2dioxaborolane $(0.93 \mathrm{~mL}, 4.96 \mathrm{mmol})$, and 2,6-dibromopyridin-4amine $(0.50 \mathrm{~g}, 1.99 \mathrm{mmol})$ in 1,4-dioxane $(7 \mathrm{~mL})$ and water $(3 \mathrm{~mL})$ was purged with nitrogen for $10 \mathrm{~min}$. $\mathrm{PdCl}_{2} \mathrm{dppf}(0.15 \mathrm{~g}, 0.20 \mathrm{mmol})$ was added, and purging was continued for a further $10 \mathrm{~min}$. The reaction was then heated to $90{ }^{\circ} \mathrm{C}$ and stirred under nitrogen for $4 \mathrm{~h}$. Upon cooling, the solution was diluted with water $(20 \mathrm{~mL})$ and extracted with ethyl acetate $(3 \times 20 \mathrm{~mL})$. The combined organic layers were dried over $\mathrm{MgSO}_{4}$, filtered, and concentrated under vacuum. The crude product was purified by chromatography on silica gel (gradient $0-50 \% \mathrm{AcOEt}$ / 
isohexane) to afford 2,6-di(prop-1-en-2-yl)pyridin-4-amine $(0.20 \mathrm{~g}$, $54 \%)$; LC-MS $m / z(\mathrm{M}+\mathrm{H})^{+}\left(\mathrm{ES}^{+}\right)$175.2; $t_{\mathrm{R}}=0.62 \mathrm{~min}$. HPLC method 2.

Step 2: 2,6-Diisopropylpyridin-4-amine (28). A solution of 2,6di(prop-1-en-2-yl)pyridin-4-amine $(0.20 \mathrm{~g}, 1.15 \mathrm{mmol})$ in methanol (4 $\mathrm{mL})$ was hydrogenated in an $\mathrm{H}$-Cube $(10 \% \mathrm{Pd} / \mathrm{C}, 30 \mathrm{~mm} \times 4 \mathrm{~mm}$, full hydrogen, $40^{\circ} \mathrm{C}, 1 \mathrm{~mL} / \mathrm{min}$ ) and concentrated under vacuum to afford 2,6-diisopropylpyridin-4-amine $(0.15 \mathrm{~g}, 75 \%)$. LC-MS $m / z(\mathrm{M}+\mathrm{H})^{+}$ $\left(\mathrm{ES}^{+}\right) 179.2 ; t_{\mathrm{R}}=1.13 \mathrm{~min}$. HPLC method 4.

Step 3: (S)-2-(3-Aminopiperidin-1-yl)-4-((2,6-diisopropylpyridin4-yl)amino)pyrimidine-5-carboxamide (19). To a stirred solution of 2,4-dichloropyrimidine-5-carboxamide $(0.97 \mathrm{~g}, 5.02 \mathrm{mmol})$ in 1,4dioxane $(20 \mathrm{~mL})$ was added 2,6-diisopropylpyridin-4-amine $38(0.69 \mathrm{~g}$, $3.86 \mathrm{mmol})$ and DIPEA $(1.35 \mathrm{~mL}, 7.73 \mathrm{mmol})$. The reaction was heated to $110^{\circ} \mathrm{C}$ and stirred for $7 \mathrm{~h}$. The mixture was allowed to cool and concentrated under vacuum. The crude product was purified by chromatography on silica gel $(0-2 \%(0.7 \mathrm{M}$ ammonia/MeOH $)$ / $\left.\mathrm{CH}_{2} \mathrm{Cl}_{2}\right)$ to afford 2-chloro-4-((2,6-diisopropylpyridin-4-yl)amino)pyrimidine-5-carboxamide $(0.91 \mathrm{~g}, 67 \%) .{ }^{1} \mathrm{H}$ NMR $(500 \mathrm{MHz}$, DMSO-d $\left.d_{6}\right) \delta 11.66(\mathrm{~s}, 1 \mathrm{H}), 8.86(\mathrm{~s}, 1 \mathrm{H}), 8.50(\mathrm{~s}, 1 \mathrm{H}), 8.04(\mathrm{~s}, 1 \mathrm{H})$, $7.40(\mathrm{~s}, 2 \mathrm{H}), 2.95(\mathrm{sept}, 2 \mathrm{H}, J=6.9 \mathrm{~Hz}), 1.24(\mathrm{~d}, 12 \mathrm{H}, J=6.9 \mathrm{~Hz})$; LCMS $m / z(\mathrm{M}+\mathrm{H})^{+}\left(\mathrm{ES}^{+}\right) 334.2 ; t_{\mathrm{R}}=2.26 \mathrm{~min}$. HPLC method 4.

To a stirred solution of 2-chloro-4-((2,6-diisopropylpyridin-4yl)amino)pyrimidine-5-carboxamide (0.91 g, $2.70 \mathrm{mmol})$ in 1,4dioxane $(20 \mathrm{~mL})$ was added $(S)$-tert-butyl piperidin-3-ylcarbamate $(0.57 \mathrm{~g}, 2.83 \mathrm{mmol})$ and DIPEA $(0.49 \mathrm{~mL}, 2.83 \mathrm{mmol})$. The reaction was heated to $90{ }^{\circ} \mathrm{C}$ and stirred for $30 \mathrm{~min}$, then allowed to cool and concentrated under vacuum. The crude product was purified by chromatography on silica gel $(0-2 \%(0.7 \mathrm{M}$ ammonia/MeOH $) /$ $\left.\mathrm{CH}_{2} \mathrm{Cl}_{2}\right)$ to afford (S)-tert-butyl (1-(5-carbamoyl-4-((2,6-diisopropylpyridin-4-yl)amino)pyrimidin-2-yl)piperidin-3-yl)carbamate (1.19 g, 88\%). LC-MS $m / z(\mathrm{M}+\mathrm{H})^{+}\left(\mathrm{ES}^{+}\right) 498.5 ; t_{\mathrm{R}}=2.49 \mathrm{~min}$. HPLC method 4 .

To a stirred solution of (S)-tert-butyl (1-(5-carbamoyl-4-((2,6diisopropylpyridin-4-yl)amino)pyrimidin-2-yl)piperidin-3-yl)carbamate $(1.19 \mathrm{~g}, 2.391 \mathrm{mmol})$ in 1,4-dioxane $(10 \mathrm{~mL})$ was added $4 \mathrm{M}$ hydrochloric acid in dioxane $(11.96 \mathrm{~mL}, 47.8 \mathrm{mmol})$, and the reaction was stirred at RT for $4 \mathrm{~h}$. The reaction mixture was then concentrated under vacuum. The residue was diluted in $\mathrm{MeOH}(0.20 \mathrm{~mL})$ and loaded onto a SCX cartridge, washing with $\mathrm{MeOH}$ ( 3 column volumes) and eluting with $1 \% \mathrm{NH}_{3} \mathrm{MeOH}$ ( 3 column volumes). The ammonical $\mathrm{MeOH}$ was removed under reduced pressure to give the title compound as a white solid $(0.85 \mathrm{~g}, 78 \%)$. Mp $225-226{ }^{\circ} \mathrm{C} ;{ }^{1} \mathrm{H}$ NMR $\left(500 \mathrm{MHz}, \mathrm{MeOD}-d_{4}\right) \delta 8.59(\mathrm{~s}, 1 \mathrm{H}), 7.44(\mathrm{~s}, 2 \mathrm{H}), 4.63(\mathrm{dd}, J=$ $12.7,4.0 \mathrm{~Hz}, 1 \mathrm{H}), 4.58-4.50(\mathrm{~m}, 1 \mathrm{H}), 3.22$ (ddd, $J=13.6,10.8,3.2 \mathrm{~Hz}$, $1 \mathrm{H}), 3.09-2.95(\mathrm{~m}, 3 \mathrm{H}), 2.88-2.77(\mathrm{~m}, 1 \mathrm{H}), 2.08-2.00(\mathrm{~m}, 1 \mathrm{H})$, $1.88-1.78(\mathrm{~m}, 1 \mathrm{H}), 1.65-1.52(\mathrm{~m}, 1 \mathrm{H}), 1.51-1.40(\mathrm{~m}, 1 \mathrm{H}), 1.30(\mathrm{dd}$, $J=7.0,2.7 \mathrm{~Hz}, 12 \mathrm{H}) ;{ }^{13} \mathrm{C}$ NMR $\left(126 \mathrm{MHz}\right.$, methanol- $\left.d_{4}\right) \delta 170.3$, 167.3, 161.0, 159.8, 158.2, 147.7, 108.0, 98.5, 51.0, 44.2, 35.9, 32.5, 23.3, 21.8; LC-MS $m / z(\mathrm{M}+\mathrm{H})^{+}\left(\mathrm{ES}^{+}\right) 398.3 ; t_{\mathrm{R}}=1.79 \mathrm{~min}$. HPLC method 4. HRMS (ES-TOF): $m / z$ calcd for $\mathrm{C}_{21} \mathrm{H}_{31} \mathrm{~N}_{7} \mathrm{ONa} 420.2482$, found $420.2473[\mathrm{M}+\mathrm{Na}]^{+}$.

\section{CONCLUSION}

We have identified highly potent and selective in vitro and in vivo probes of CaMK1 kinases through a structure-based design approach. These probes should be of utility to researchers working on CaMK1 biology in vitro or who wish to investigate the effects of targeting the peripheral function of CaMK1 enzymes.

\section{ASSOCIATED CONTENT}

\section{SI Supporting Information}

The Supporting Information is available free of charge at https://pubs.acs.org/doi/10.1021/acs.jmedchem.9b01803.

Molecular SMILES strings and in vitro results including number of replicates and standard deviation values (CSV) HPLC traces for 1-19 (PDF)
Experimental data from X-ray crystal structures, experimental details for DIO mouse OGTT study, full Eurofins Discover X profiles, and NMR spectra of 18 and 19 (PDF) Structure of compound 8 bound to CaMK1D (PDB) Structure of compound $\mathbf{1 8}$ bound to CaMK1D (PDB) Structure of compound 19 bound to CaMK1D (PDB)

\section{Accession Codes}

X-ray coordinates and structures factors have been deposited in the Protein Data Bank under the following accession codes: compound 8, PDB 6T6F; compound 18, PDB 6T28; compound 19, PDB 6T29. Authors will release the atomic coordinates upon article publication.

\section{AUTHOR INFORMATION}

\section{Corresponding Author}

Sam Butterworth - Division of Pharmacy and Optometry, School of Health Sciences, Manchester Academic Health Sciences Centre, University of Manchester, Manchester M13 9PL, U.K.; (1) orcid.org/0000-0002-6549-3753;

Email: sam.butterworth@manchester.ac.uk

\section{Authors}

Christophe Fromont - Centre for Biomolecular Sciences and School of Pharmacy, University of Nottingham, Nottingham NG7 2RD, U.K.

Alessio Atzori - Centre for Biomolecular Sciences and School of Pharmacy, University of Nottingham, Nottingham NG7 2RD, U.K.

Divneet Kaur - Centre for Biomolecular Sciences and School of Pharmacy, University of Nottingham, Nottingham NG7 2RD, U.K.

Lubna Hashmi - Centre for Biomolecular Sciences and School of Pharmacy, University of Nottingham, Nottingham NG7 2RD, U.K.

Graziella Greco - School of Pharmacy, College of Medical and Dental Sciences, University of Birmingham, Edgbaston B15 2TT, U.K.

Alejandro Cabanillas - School of Pharmacy, College of Medical and Dental Sciences, University of Birmingham, Edgbaston B15 2TT, U.K.

Huy Van Nguyen - School of Pharmacy, College of Medical and Dental Sciences, University of Birmingham, Edgbaston B15 2TT, U.K.; (1) orcid.org/0000-0002-3985-1510

D. Heulyn Jones - Division of Pharmacy and Optometry, School of Health Sciences, Manchester Academic Health Sciences Centre, University of Manchester, Manchester M13 9PL, U.K.

Miguel Garzón - Division of Pharmacy and Optometry, School of Health Sciences, Manchester Academic Health Sciences Centre, University of Manchester, Manchester M13 9PL, U.K.

Ana Varela - Division of Pharmacy and Optometry, School of Health Sciences, Manchester Academic Health Sciences Centre, University of Manchester, Manchester M13 9PL, U.K.

Brett Stevenson - Sygnature Discovery, Nottingham NG1 1GF, U.K.

Greg P. Iacobini - Sygnature Discovery, Nottingham NG1 1GF, U.K.

Marc Lenoir - Institute of Cancer and Genomic Sciences, University of Birmingham, Birmingham B15 2TT, U.K.

Sundaresan Rajesh - Institute of Cancer and Genomic Sciences, University of Birmingham, Birmingham B15 2TT, U.K.

Clare Box - Institute of Cancer and Genomic Sciences, University of Birmingham, Birmingham B15 2TT, U.K. 
Jitendra Kumar - Department of Biochemistry, University of Alberta, Edmonton, Alberta T6G 2H7, Canada

Paige Grant - Department of Biochemistry, University of Alberta, Edmonton, Alberta T6G 2H7, Canada

Vera Novitskaya - Institute of Cancer and Genomic Sciences, University of Birmingham, Birmingham B15 2TT, U.K.

Juliet Morgan - Sygnature Discovery, Nottingham NG1 1GF, U.K.

Fiona J. Sorrell - Structural Genomics Consortium and Target Discovery Institute, Nuffield Department of Clinical Medicine, University of Oxford, Oxford OX3 7DQ U.K.

Clara Redondo - Structural Genomics Consortium and Target Discovery Institute, Nuffield Department of Clinical Medicine, University of Oxford, Oxford OX3 7DQ, U.K.

Andreas Kramer - Structural Genomics Consortium and Buchmann Institute for Molecular Life Sciences, Institute for Pharmaceutical Chemistry, Johann Wolfgang Goethe-University, 60438 Frankfurt am Main, Germany

C. John Harris - CJH Consultants, Ford Cottage, Brockenhurst, Hants SO42 7UQ, U.K.

Brendan Leighton - The Research Network, Sandwich CT13 9NJ, U.K.

Steven P. Vickers - RenaSci Limited, Nottingham NG1 1GF, U.K.

Sharon C. Cheetham - RenaSci Limited, Nottingham NG1 1GF, U.K.

Colin Kenyon - DST/NRF Centre of Excellence for Biomedical Tuberculosis Research, SAMRC Centre for Molecular and Cellular Biology, Division of Molecular Biology and Human Genetics, Faculty of Medicine and Health Sciences, Stellenbosch University, Cape Town 8000, South Africa

Anna M. Grabowska - Ex Vivo Cancer Pharmacology Centre of Excellence, Cancer Biology, Division of Cancer and Stem Cells, School of Medicine, University of Nottingham, Nottingham NG7 2RD, U.K.

Michael Overduin - Department of Biochemistry, University of Alberta, Edmonton, Alberta T6G 2H7, Canada

Fedor Berditchevski - Institute of Cancer and Genomic Sciences, University of Birmingham, Birmingham B15 2TT, U.K.

Chris J. Weston - Centre for Liver Research, Institute of Immunology and Immunotherapy, University of Birmingham, Birmingham B15 2TT, U.K.; NIHR Birmingham Biomedical Research Centre, University Hospitals Birmingham NHS Foundation Trust and University of Birmingham, Birmingham B15 2TT, U.K.

Stefan Knapp - Structural Genomics Consortium and Buchmann Institute for Molecular Life Sciences, Institute for Pharmaceutical Chemistry, Johann Wolfgang Goethe-University, 60438

Frankfurt am Main, Germany; 이이이.org/0000-0001-59956494

Peter M. Fischer - Centre for Biomolecular Sciences and School of Pharmacy, University of Nottingham, Nottingham NG7 2RD,

U.K.; (1) orcid.org/0000-0002-5866-9271

Complete contact information is available at:

https://pubs.acs.org/10.1021/acs.jmedchem.9b01803

\section{Author Contributions}

Compounds were designed and synthesized by C.F., A.A., D.K., L.H., G.G., A.C., H.V.N., D.H.J., M.G.S., A.V.R., B.S., G.P.I., C.J.H., P.M.F., and S.B. In vitro biology studies were designed and performed by M.L., S.R., C.B., J.K., P.G., V.N., J.M., A.C.R., A.K., C.K., M.O., S.K., and F.B. Crystal structure analysis was performed by F.S. and A.K. In vivo DIO mice studies were designed by S.B., B.L., C.J.W., S.C.C., and S.P.V. The data obtained were interpreted by all authors. All authors have given approval to the final version of the manuscript.

\section{Funding}

This work was supported by the Wellcome Trust [103022 and 202708] and MRC [MC_PC_15032]. C.J.W. is funded by the NIHR Birmingham Biomedical Research Centre at the University Hospitals Birmingham, NHS Foundation Trust, and the University of Birmingham. This paper presents independent research supported by the NIHR Birmingham Biomedical Research Centre at the University Hospitals Birmingham NHS Foundation Trust and the University of Birmingham.

\section{Notes}

The views expressed are those of the author(s) and not necessarily those of the NHS, the NIHR, or the Department of Health and Social Care. In vivo studies were conducted in the UK in accordance with the Animal Ethical Review Group, University of Birmingham, and UK Home Office legislation, the Animal Scientific Procedures Act 1986, under Home Office project licenses 70/8420 (Saretius, PK studies) and 30/3208 (RenaSci, efficacy studies in DIO mice).

The authors declare no competing financial interest.

\section{ACKNOWLEDGMENTS}

KINOMEscan TREEspot images generated using TREEspot Software Tool and reprinted with permission from KINOMEscan, a division of DiscoveRx Corporation, Copyright 2010 DISCOVERX CORPORATION. DIO mice studies were conducted by RenaSci (Nottingham, UK). Marvin, Calculator Plugins, and JChem Base were used for drawing, displaying, and characterizing chemical structures, structure searching, and chemical database access and management, ChemAxon (http:// www.chemaxon.com).

\section{ABBREVIATIONS}

CaMK1, calmodulin-dependent kinase; GWAS, genome-wide association studies; FOXA1, hepatocyte nuclear factor $3-\alpha$; siRNA, small interfering ribonucleic acid; CRTC2/TORC2, CREB regulated transcription coactivator 2 ; TNBC, triplenegative breast cancer; SYK, spleen tyrosine kinase; DIO, dietinduced obese; OGTT, oral glucose tolerance test

\section{REFERENCES}

(1) Parkinson, H.; Kapushesky, M.; Shojatalab, M.; Abeygunawardena, N.; Coulson, R.; Farne, A.; Holloway, E.; Kolesnykov, N.; Lilja, P.; Lukk, M.; Mani, R.; Rayner, T.; Sharma, A.; William, E.; Sarkans, U.; Brazma, A. Array Express-a Public Database of Microarray Experiments and Gene Expression Profiles. Nucleic Acids Res. 2007, 35 (Database), D747-750.

(2) Wayman, G. A.; Lee, Y.-S.; Tokumitsu, H.; Silva, A.; Soderling, T. R. Calmodulin-Kinases: Modulators of Neuronal Development and Plasticity. Neuron 2008, 59 (6), 914-931.

(3) Zeggini, E.; Scott, L. J.; Saxena, R.; Voight, B. F.; Marchini, J. L.; Hu, T.; de Bakker, P. I.; Abecasis, G. R.; Almgren, P.; Andersen, G.; Ardlie, K.; Boström, K. B.; Bergman, R. N.; Bonnycastle, L. L.; BorchJohnsen, K.; Burtt, N. P.; Chen, H.; Chines, P. S.; Daly, M. J.; Deodhar, P.; Ding, C. J.; Doney, A. S.; Duren, W. L.; Elliott, K. S.; Erdos, M. R.; Frayling, T. M.; Freathy, R. M.; Gianniny, L.; Grallert, H.; Grarup, N.; Groves, C. J.; Guiducci, C.; Hansen, T.; Herder, C.; Hitman, G. A.; Hughes, T. E.; Isomaa, B.; Jackson, A. U.; Jørgensen, T.; Kong, A.; Kubalanza, K.; Kuruvilla, F. G.; Kuusisto, J.; Langenberg, C.; Lango, H.; Lauritzen, T.; Li, Y.; Lindgren, C. M.; Lyssenko, V.; Marvelle, A. F.; 
Meisinger, C.; Midthjell, K.; Mohlke, K. L.; Morken, M. A.; Morris, A. D.; Narisu, N.; Nilsson, P.; Owen, K. R.; Palmer, C. N.; Payne, F.; Perry, J. R.; Pettersen, E.; Platou, C.; Prokopenko, I.; Qi, L.; Qin, L.; Rayner, N. W.; Rees, M.; Roix, J. J.; Sandbaek, A.; Shields, B.; Sjögren, M.; Steinthorsdottir, V.; Stringham, H. M.; Swift, A. J.; Thorleifsson, G.; Thorsteinsdottir, U.; Timpson, N. J.; Tuomi, T.; Tuomilehto, J.; Walker, M.; Watanabe, R. M.; Weedon, M. N.; Willer, C. J.; Illig, T.; Hveem, K.; Hu, F. B.; Laakso, M.; Stefansson, K.; Pedersen, O.; Wareham, N. J.; Barroso, I.; Hattersley, A. T.; Collins, F. S.; Groop, L.; McCarthy, M. I.; Boehnke, M.; Altshuler, D.; Wellcome Trust Case Control Consortium. Meta-Analysis of Genome-Wide Association Data and Large-Scale Replication Identifies Additional Susceptibility Loci for Type 2 Diabetes. Nat. Genet. 2008, 40 (5), 638-645.

(4) Shu, X. O.; Long, J.; Cai, Q.; Qi, L.; Xiang, Y.-B.; Cho, Y. S.; Tai, E. S.; Li, X.; Lin, X.; Chow, W.-H.; Go, M. J.; Seielstad, M.; Bao, W.; Li, H.; Cornelis, M. C.; Yu, K.; Wen, W.; Shi, J.; Han, B. G.; Sim, X. L.; Liu, L.; Qi, Q.; Kim, H. L.; Ng, D. P.; Lee, J. Y.; Kim, Y. J.; Li, C.; Gao, Y. T.; Zheng, W.; Hu, F. B. Identification of New Genetic Risk Variants for Type 2 Diabetes. PLoS Genet. 2010, 6 (9), No. e1001127.

(5) Kooner, J. S.; Saleheen, D.; Sim, X.; Sehmi, J.; Zhang, W.; Frossard, P.; Been, L. F.; Chia, K.-S.; Dimas, A. S.; Hassanali, N.; Jafar, T.; Jowett, J. B.; Li, X.; Radha, V.; Rees, S. D.; Takeuchi, F.; Young, R.; Aung, T.; Basit, A.; Chidambaram, M.; Das, D.; Grundberg, E.; Hedman, A. K.; Hydrie, Z. I.; Islam, M.; Khor, C. C.; Kowlessur, S.; Kristensen, M. M.; Liju, S.; Lim, W. Y.; Matthews, D. R.; Liu, J.; Morris, A. P.; Nica, A. C.; Pinidiyapathirage, J. M.; Prokopenko, I.; Rasheed, A.; Samuel, M.; Shah, N.; Shera, A. S.; Small, K. S.; Suo, C.; Wickremasinghe, A. R.; Wong, T. Y.; Yang, M.; Zhang, F.; Abecasis, G. R.; Barnett, A. H.; Caulfield, M.; Deloukas, P.; Frayling, T. M.; Froguel, P.; Kato, N.; Katulanda, P.; Kelly, M. A.; Liang, J.; Mohan, V.; Sanghera, D. K.; Scott, J.; Seielstad, M.; Zimmet, P. Z.; Elliott, P.; Teo, Y. Y.; McCarthy, M. I.; Danesh, J.; Tai, E. S.; Chambers, J. C.; DIAbetes Genetics Replication And Meta-analysis (DIAGRAM) Consortium; MuTHER Consortium. Genome-Wide Association Study in Individuals of South Asian Ancestry Identifies Six New Type 2 Diabetes Susceptibility Loci. Nat. Genet. 2011, 43 (10), 984-989.

(6) Morris, A. P.; Voight, B. F.; Teslovich, T. M.; Ferreira, T.; Segrè, A. V.; Steinthorsdottir, V.; Strawbridge, R. J.; Khan, H.; Grallert, H.; Mahajan, A.; Prokopenko, I.; Kang, H. M.; Dina, C.; Esko, T.; Fraser, R. M.; Kanoni, S.; Kumar, A.; Lagou, V.; Langenberg, C.; Luan, J.; Lindgren, C. M.; Müller-Nurasyid, M.; Pechlivanis, S.; Rayner, N. W.; Scott, L. J.; Wiltshire, S.; Yengo, L.; Kinnunen, L.; Rossin, E. J.; Raychaudhuri, S.; Johnson, A. D.; Dimas, A. S.; Loos, R. J.; Vedantam, S.; Chen, H.; Florez, J. C.; Fox, C.; Liu, C. T.; Rybin, D.; Couper, D. J.; Kao, W. H.; Li, M.; Cornelis, M. C.; Kraft, P.; Sun, Q.; van Dam, R. M.; Stringham, H. M.; Chines, P. S.; Fischer, K.; Fontanillas, P.; Holmen, O. L.; Hunt, S. E.; Jackson, A. U.; Kong, A.; Lawrence, R.; Meyer, J.; Perry, J. R.; Platou, C. G.; Potter, S.; Rehnberg, E.; Robertson, N.; Sivapalaratnam, S.; Stančáková, A.; Stirrups, K.; Thorleifsson, G.; Tikkanen, E.; Wood, A. R.; Almgren, P.; Atalay, M.; Benediktsson, R.; Bonnycastle, L. L.; Burtt, N.; Carey, J.; Charpentier, G.; Crenshaw, A. T.; Doney, A. S.; Dorkhan, M.; Edkins, S.; Emilsson, V.; Eury, E.; Forsen, T.; Gertow, K.; Gigante, B.; Grant, G. B.; Groves, C. J.; Guiducci, C.; Herder, C.; Hreidarsson, A. B.; Hui, J.; James, A.; Jonsson, A.; Rathmann, W.; Klopp, N.; Kravic, J.; Krjutškov, K.; Langford, C.; Leander, K.; Lindholm, E.; Lobbens, S.; Männistö, S.; Mirza, G.; Mühleisen, T. W.; Musk, B.; Parkin, M.; Rallidis, L.; Saramies, J.; Sennblad, B.; Shah, S.; Sigurđsson, G.; Silveira, A.; Steinbach, G.; Thorand, B.; Trakalo, J.; Veglia, F.; Wennauer, R.; Winckler, W.; Zabaneh, D.; Campbell, H.; van Duijn, C.; Uitterlinden, A. G.; Hofman, A.; Sijbrands, E.; Abecasis, G. R.; Owen, K. R.; Zeggini, E.; Trip, M. D.; Forouhi, N. G.; Syvänen, A. C.; Eriksson, J. G.; Peltonen, L.; Nöthen, M. M.; Balkau, B.; Palmer, C. N.; Lyssenko, V.; Tuomi, T.; Isomaa, B.; Hunter, D. J.; Qi, L.; Shuldiner, A. R.; Roden, M.; Barroso, I.; Wilsgaard, T.; Beilby, J.; Hovingh, K.; Price, J. F.; Wilson, J. F.; Rauramaa, R.; Lakka, T. A.; Lind, L.; Dedoussis, G.; Njølstad, I.; Pedersen, N. L.; Khaw, K. T.; Wareham, N. J.; Keinanen-Kiukaanniemi, S. M.; Saaristo, T. E.; Korpi-Hyövälti, E.; Saltevo, J.; Laakso, M.; Kuusisto, J.; Metspalu, A.; Collins, F. S.; Mohlke, K. L.; Bergman, R. N.; Tuomilehto, J.;
Boehm, B. O.; Gieger, C.; Hveem, K.; Cauchi, S.; Froguel, P.; Baldassarre, D.; Tremoli, E.; Humphries, S. E.; Saleheen, D.; Danesh, J.; Ingelsson, E.; Ripatti, S.; Salomaa, V.; Erbel, R.; Jöckel, K. H.; Moebus, S.; Peters, A.; Illig, T.; de Faire, U.; Hamsten, A.; Morris, A. D.; Donnelly, P. J.; Frayling, T. M.; Hattersley, A. T.; Boerwinkle, E.; Melander, O.; Kathiresan, S.; Nilsson, P. M.; Deloukas, P.; Thorsteinsdottir, U.; Groop, L. C.; Stefansson, K.; Hu, F.; Pankow, J. S.; Dupuis, J.; Meigs, J. B.; Altshuler, D.; Boehnke, M.; McCarthy, M. I.; DIAbetes Genetics Replication And Meta-analysis (DIAGRAM) Consortium; Wellcome Trust Case Control Consortium; MetaAnalyses of Glucose and Insulin-related traits Consortium (MAGIC) Investigators; Genetic, Investigation of ANthropometric, Traits (GIANT) Consortium; Asian Genetic Epidemiology Network-Type 2 Diabetes (AGEN-T2D) Consortium; South Asian Type 2 Diabetes (SAT2D) Consortium. Large-Scale Association Analysis Provides Insights into the Genetic Architecture and Pathophysiology of Type 2 Diabetes. Nat. Genet. 2012, 44 (9), 981-990.

(7) Fogarty, M. P.; Cannon, M. E.; Vadlamudi, S.; Gaulton, K. J.; Mohlke, K. L. Identification of a Regulatory Variant That Binds FOXA1 and FOXA2 at the CDC123/CAMK1D Type 2 Diabetes GWAS Locus. PLoS Genet. 2014, 10 (9), No. e1004633.

(8) Haney, S.; Zhao, J.; Tiwari, S.; Eng, K.; Guey, L. T.; Tien, E. RNAi Screening in Primary Human Hepatocytes of Genes Implicated in Genome-Wide Association Studies for Roles in Type 2 Diabetes Identifies Roles for CAMK1D and CDKAL1, among Others, in Hepatic Glucose Regulation. PLoS One 2013, 8 (6), No. e64946.

(9) Saberi, M.; Bjelica, D.; Schenk, S.; Imamura, T.; Bandyopadhyay, G.; Li, P.; Jadhar, V.; Vargeese, C.; Wang, W.; Bowman, K.; Zhang, Y.; Polisky, B.; Olefsky, J. M. Novel Liver-Specific TORC2 SiRNA Corrects Hyperglycemia in Rodent Models of Type 2 Diabetes. Am. J. Physiol. Metab. 2009, 297 (5), E1137-E1146.

(10) Wang, Y.; Inoue, H.; Ravnskjaer, K.; Viste, K.; Miller, N.; Liu, Y.; Hedrick, S.; Vera, L.; Montminy, M. Targeted Disruption of the CREB Coactivator Crtc2 Increases Insulin Sensitivity. Proc. Natl. Acad. Sci. U. S. A. 2010, 107 (7), 3087-3092.

(11) Erion, D. M.; Kotas, M. E.; McGlashon, J.; Yonemitsu, S.; Hsiao, J. J.; Nagai, Y.; Iwasaki, T.; Murray, S. F.; Bhanot, S.; Cline, G. W.; Samuel, V. T. CAMP-Responsive Element-Binding Protein (CREB)Regulated Transcription Coactivator 2 (CRTC2) Promotes Glucagon Clearance and Hepatic Amino Acid Catabolism to Regulate Glucose Homeostasis. J. Biol. Chem. 2013, 288 (22), 16167-16176.

(12) Loo, L. W. M.; Wang, Y.; Flynn, E. M.; Lund, M. J.; Bowles, E. J. A.; Buist, D. S. M.; Liff, J. M.; Flagg, E. W.; Coates, R. J.; Eley, J. W.; Hsu, L.; Porter, P. L. Genome-Wide Copy Number Alterations in Subtypes of Invasive Breast Cancers in Young White and African American Women. Breast Cancer Res. Treat. 2011, 127 (1), 297-308.

(13) Shavers, V. L.; Harlan, L. C.; Stevens, J. L. Racial/Ethnic Variation in Clinical Presentation, Treatment, and Survival among Breast Cancer Patients under Age 35. Cancer 2003, 97 (1), 134-147.

(14) Bergamaschi, A.; Kim, Y. H.; Kwei, K. A.; La Choi, Y.; Bocanegra, M.; Langerød, A.; Han, W.; Noh, D.-Y.; Huntsman, D. G.; Jeffrey, S. S.; Børresen-Dale, A.-L.; Pollack, J. R. CAMK1D Amplification Implicated in Epithelial-Mesenchymal Transition in Basal-like Breast Cancer. Mol. Oncol. 2008, 2 (4), 327-339.

(15) Yamada, T.; Suzuki, M.; Satoh, H.; Kihara-Negishi, F.; Nakano, H.; Oikawa, T. Effects of PU.1-Induced Mouse Calcium-CalmodulinDependent Kinase I-like Kinase (CKLiK) on Apoptosis of Murine Erythroleukemia Cells. Exp. Cell Res. 2004, 294 (1), 39-50.

(16) Hisamichi, H.; Naito, R.; Toyoshima, A.; Kawano, N.; Ichikawa, A.; Orita, A.; Orita, M.; Hamada, N.; Takeuchi, M.; Ohta, M.; Tsukamoto, S-i. Synthetic Studies on Novel Syk Inhibitors. Part 1: Synthesis and Structure-Activity Relationships of Pyrimidine-5Carboxamide Derivatives. Bioorg. Med. Chem. 2005, 13 (16), 49364951.

(17) Liddle, J.; Atkinson, F. L.; Barker, M. D.; Carter, P. S.; Curtis, N. R.; Davis, R. P.; Douault, C.; Dickson, M. C.; Elwes, D.; Garton, N. S.; Gray, M.; Hayhow, T. G.; Hobbs, C. I.; Jones, E.; Leach, S.; Leavens, K.; Lewis, H. D.; McCleary, S.; Neu, M.; Patel, V. K.; Preston, A. G.; Ramirez-Molina, C.; Shipley, T. J.; Skone, P. A.; Smithers, N.; Somers, 
D. O.; Walker, A. L.; Watson, R. J.; Weingarten, G. G. Discovery of GSK143, a Highly Potent, Selective and Orally Efficacious Spleen Tyrosine Kinase Inhibitor. Bioorg. Med. Chem. Lett. 2011, 21 (20), 6188-6194.

(18) Thoma, G.; Smith, A. B.; van Eis, M. J.; Vangrevelinghe, E.; Blanz, J.; Aichholz, R.; Littlewood-Evans, A.; Lee, C. C.; Liu, H.; Zerwes, H.-G. Discovery and Profiling of a Selective and Efficacious Syk Inhibitor. J. Med. Chem. 2015, 58 (4), 1950-1963.

(19) Ellis, J. M.; Altman, M. D.; Bass, A.; Butcher, J. W.; Byford, A. J.; Donofrio, A.; Galloway, S.; Haidle, A. M.; Jewell, J.; Kelly, N.; Leccese, E. K.; Lee, S.; Maddess, M.; Miller, J. R.; Moy, L. Y.; Osimboni, E.; Otte, R. D.; Reddy, M. V.; Spencer, K.; Sun, B.; Vincent, S. H.; Ward, G. J.; Woo, G. H.; Yang, C.; Houshyar, H.; Northrup, A. B. Overcoming Mutagenicity and Ion Channel Activity: Optimization of Selective Spleen Tyrosine Kinase Inhibitors. J. Med. Chem. 2015, 58 (4), 19291939.

(20) Gao, Y.; Davies, S. P.; Augustin, M.; Woodward, A.; Patel, U. A.; Kovelman, R.; Harvey, K. J. A Broad Activity Screen in Support of a Chemogenomic Map for Kinase Signalling Research and Drug Discovery. Biochem. J. 2013, 451 (2), 313-328.

(21) Shang, R.; Ji, D.-S.; Chu, L.; Fu, Y.; Liu, L. Synthesis of $\alpha$-Aryl Nitriles through Palladium-Catalyzed Decarboxylative Coupling of Cyanoacetate Salts with Aryl Halides and Triflates. Angew. Chem., Int. Ed. 2011, 50 (19), 4470-4474. 